\title{
EFFECT OF PILATES METHOD ON PHYSICAL FITNESS \\ RELATED TO HEALTH IN THE ELDERLY: A SYSTEMATIC REVIEW
}

\author{
EFEITO DO MÉTODO PILATES NA APTIDÃO FISICA RELACIONADA À SAÚDE DE IDOSOS: \\ UMAREVISÃO SISTEMÁTICA \\ EFECTO DEL MÉTODO PILATES EN LA APTITUD FISICA RELACIONADA A LA SALUD DE INDIVIDUOS \\ DE LA TERCERA EDAD: UNA REVISIÓN SISTEMÁTICA
}

Gabrielle Critine Moura

Fernandes Pucci ${ }^{1}$

(Physiotherapist)

Eduardo Borba Neves

(Physiotherapist)

Francisco José Félix Saavedra'

(Physical Education Professional)

1. Universidade de Trás-os-Montes e Alto Douro, Vila Real, Portugal.

2. Universidade Tecnológica Federal do Paraná, Curitiba, PR, Brazil.

\section{Correspondence:}

Eduardo Borba Neves. Instituto de Pesquisa da Capacitação Física do Exército - IPCFEx

Av. João Luiz Alves, s/n - Urca, Rio de Janeiro, RJ, Brazil 22291-090 borbaneves@hotmail.com

\begin{abstract}
The objective of this review was to analyze the evidence of Pilates in physical fitness related to health in the elderly. The article indexing databases (Pubmed, Medline, Science Direct, Scielo, Lilacs, and Cochrane) were reviewed along with the Pilates, elderly and aging descriptors. A total of 41 studies with a randomized experimental and quasi-experimental design met the inclusion criteria. The selection of the studies was carried out by two researchers and the quality of the articles was assessed using the PEDro scale. Interventions ranged from 4-24 weeks with 1-3 sessions/week, and balance was the most investigated variable. The studies included in this review indicate that Pilates improves health status in the elderly, promoting gains in balance, muscle strength, flexibility, functional autonomy, muscular endurance, body composition and aerobic endurance. Despite these findings, some variables need to be further investigated. Level of Evidence Il; Systematic review.
\end{abstract}

Keywords: Pilates training; Elderly; Aging.

\section{RESUMO}

O objetivo desta revisão foi analisar as evidências do Pilates na aptidão física relacionada com a saúde de idosos. Foram revisadas as bases de indexação de artigos (Pubmed, Medline, Science Direct, Scielo, Lilacs e Cochrane), com os descritores "Método pilates, idosos e envelhecimento". Atenderam os critérios de inclusão 41 estudos com delineamento randomizado experimental " "quase experimental." A seleção dos estudos foi realizada por dois pesquisadores e a qualidade dos artigos foi avaliada pela escala PEDro. As intervenções variaram entre 4 e 24 semanas, de 1 a 3 sessões/semana e a variável mais investigada foi o equilíbrio. Os estudos incluidos nesta revisão indicam que a prática de Pilates melhora as condições de saúde dos idosos, promovendo ganhos de equilibrio, força muscular, flexibilidade, autonomia funcional, resistência muscular, composição corporal e resistência aeróbica. Apesar destes achados, algumas variáveis precisam ser mais investigadas. Nível de Evidência ll; Revisão sistemática.

\section{Descritores: Método pilates; Idosos; Envelhecimento.}

\section{RESUMEN}

El objetivo de esta revisión fue analizar las evidencias del Pilates en la aptitud física relacionada a la salud de individuos de la tercera edad. Se revisaron las bases indexadoras de artículos (Pubmed, Medline, Science Direct, Scielo, Lilacs, y Cochrane), con los descriptores "Método pilates, ancianos y envejecimiento". Se cumplieron los criterios de inclusión 41 estudios con delineación experimental aleatorizada y "casi experimental." La selección de los estudios fue realizada por dos investigadores y la calidad de los artículos fue evaluada a través de la escala PEDro. Las intervenciones variaron entre 4-24 semanas, de 1-3 sesiones/semana y la variable más investigada fue el equilibrio. Los estudios incluidos en esta revisión indican que la práctica del Pilates mejora las condiciones de salud de los individuos de la tercera edad, promoviendo aumentos de equilibrio, fuerza muscular, flexibilidad, autonomía funcional, resistencia muscular, composición corporal y resistencia aeróbica. A pesar de estos hallazgos, algunas variables necesitan ser más investigadas. Nível de Evidencia ll; Revision sistemática.

Descriptores: Método pilates; Ancianos; Envejecimiento.

\section{INTRODUCTION}

Aging is a global phenomenon and the elderly population has the fastest growing in the world in both developed and developing countries'. In Brazil, the elderly population corresponds to $14.4 \%$ of the total population and it is estimated that in 2025 Brazil will have the sixth largest elderly population in the world ${ }^{2,3}$. Although the elderly are living more and more it is known that most of these years are compromised by diseases and limitations. Thus, public policies are needed to promote aging with health and quality of life for the elderly and ensure adequate care for their needs.

Aging is a dynamic and progressive process in living beings, leading to the progressive losses of functional abilities of the organism and consequently leading to death ${ }^{4}$. One of the main ways to avoid and/ 
or minimize the physical, social and psychological decline that often accompanies aging is the regular practice of physical exercises ${ }^{5,6}$. The regular practice of physical exercises contributes to the maintenance and improvement of the physical fitness of the elderly, making them more independent ${ }^{7}$.

Physical fitness is the ability to perform day-to-day activities with the least amount of effort. Physical fitness related to health refers to the physical condition in the capacities that are related mainly to people's quality of life such as flexibility, aerobic endurance, strength and body composition ${ }^{8}$. Elderly people who perform physical exercises reduce the incidence of falls and the risk of fractures ${ }^{9}$, have a lower risk of developing depression and dementia ${ }^{10}$, and improve physical fitness ${ }^{11}$. In general, the elderly should perform moderate-intensity physical activities for at least 150 minutes/week or 75 minutes/week of vigorous activities and include flexibility, strength, and balance exercises at least two days a week in their routine ${ }^{7,12}$. In this sense, Pilates is an indicated activity for the development of flexibility, strength and balance in the elderly ${ }^{11,13}$. Pilates consists of physical exercises whose main characteristic is resistance work and dynamic stretching, performed in conjunction with breathing and respecting the principles of body control, precision, centralization, fluidity of movement and concentration ${ }^{14}$.

Pilates is a rising activity, so studies that investigated the effects of Pilates among the elderly are recent and the evidence is limited. Thus, the present study aims to conduct a systematic review of the literature on the effects of Pilates on physical fitness related to health in the elderly.

\section{METHOD}

The present systematic review was elaborated from a search of quantitative studies in the following periodicals: Pubmed, Medline, Science Direct, Scielo, Web of Science and Scopus. The terms Pilates, elderly, aging and aged were used as descriptors. The search comprised the entire period of existence of the bases until November 2017 and was carried out with the descriptors in English. The review was carried out in four stages of evaluation that included the search of articles and the reading of titles, abstracts and full texts. These evaluation stages were carried out by two researchers independently and when there was divergence between them a third researcher was called.

Included in the review there were articles that filled in the following criteria: a) analyzed the effect of Pilates on the physical fitness related to the health of apparently healthy elderly; b) included in the sample individuals aged $\geq 60$ years; c) studies written in English or Portuguese and d) experimental or quasi-experimental studies. Studies with children, adolescents and adults as well as book chapters, theses, dissertations, review articles, case studies, editorials and other theoretical articles were excluded from the analysis.

The quality of the articles was analyzed using the PEDro scale ${ }^{15}$, which was used in similar studies ${ }^{16,17}$. This scale consists of analyzing, through 11 items, two characteristics related to the quality of the articles, that are the internal validity and if the study presents enough statistical information that makes it comprehensible. Scale scores range from 0 to 10 (the first item on the list is not counted), and studies with a score greater than 5 are considered high quality ${ }^{16,17}$.

\section{RESULTS}

he articles were published as of 2007, with the majority coming from Brazil ( $n=20,48.8 \%$ ). The sample size ranged from 8 to 303 individuals. As for sex, women were included in all studies, while 17 (41.46\%) included both sexes. The most investigated variable was the balance $(n=22$, $53.6 \%)$, followed by muscle strength ( $n=16,39 \%)$, functional autonomy $(n=9,21.9 \%)$, flexibility $(n=8,19.5 \%)$, body composition $(n=5,12.2 \%)$, muscular endurance $(n=2,4.9 \%)$ and aerobic resistance $(n=2,4.9 \%)$. The intervention period varied from 4 to 24 weeks, with the majority of programs lasting 12 weeks ( $n=15,36.6 \%$ ), performed from 1 to 3 sessions/ week, with 50-60 minutes/session. Some studies have not reported the attendance of the elderly in class, as well as the level of intensity and the description of the exercises. The quality of the articles included in the systematic review was analyzed using the PEDro scale, reaching the average score of 3.9. Thirteen articles (31.7\%) scored higher than 5 points on the PEDro scale, indicating a high methodological quality of the article. Other characteristics about the studies are shown in Apendix 1. A total of 41 articles were included in this systematic review. The titles, abstracts and full texts were read during each stage, repeated articles and those that did not fit the study inclusion criteria were excluded (Figure 1).

\section{DISCUSSION}

This systematic review was conducted with the objective of analyzing evidence on the effect of Pilates on the physical fitness related to the health of apparently healthy elderly. It is believed that Pilates exercises can bring health benefits to the elderly, as it has been reported in studies with adults ${ }^{16,18,19}$, but some variables have been little investigated and need to be better evaluated in order to reach a conclusion. Most of the articles included in this review are recent, which shows that Pilates is being increasingly disseminated and practiced among the elderly. Consequently, there is a greater interest from part of the researchers in investigating more about the effects of the modality in this population. The studies were composed, predominantly, by women, and there was no study with a sample composed solely of males. In fact, there is a greater demand and commitment of women to Pilates, which may explain such a finding, as well as the fact that women are more concerned about taking care of their health ${ }^{20}$. Regarding the methodological quality of the studies, the average score was 3.9 and was below the average of the indexed articles in PEDro, which is $5.1^{21}$. Only $17 \%(n=7)$ of the studies included in this review were classified as high methodological quality, so some factors such as statistical information and internal validity should be analyzed with caution.

Although studies have shown a positive relationship between Pilates and physical fitness it is not clear how much time it takes for these benefits to be achieved, it was observed that some variables need more time than others to take effect. Regarding the number of sessions, a large variation was observed among the reviewed studies, with most of the studies opting for a 12-week intervention.

\section{Balance}

Of the 22 articles that analyzed the effect of balance after Pilates practice on the elderly only 6 did not find positive results. According to the results of this review, there is strong evidence that Pilates improves the balance of the elderly, both static and dynamic. Hyun et al. (2014) ${ }^{22}$ and Barker et al. (2015) $)^{23}$ assessed several aspects of balance and found improvements in dynamic and static balance after 12 weeks of Pilates. Roller et al. (2017)24 found the same positive results with a shorter practice period, 10 weeks of Pilates, only once a week. In the article by Bird et al. $(2012)^{25}$, a program with 15 sessions of Pilates improved the static and dynamic balance of the participants, but although the balance improved significantly in the Pilates group there was no difference between the Pilates group and the control group. Following this study, Bird et al. $(2014)^{26}$ concluded that the improvement in balance remained even after one year after the intervention.

Some studies have investigated the balance related to falls. It is known that, in order to reduce the number of falls, the programs must be multifactorial, aiming at not only isolated equilibrium work, but also being 


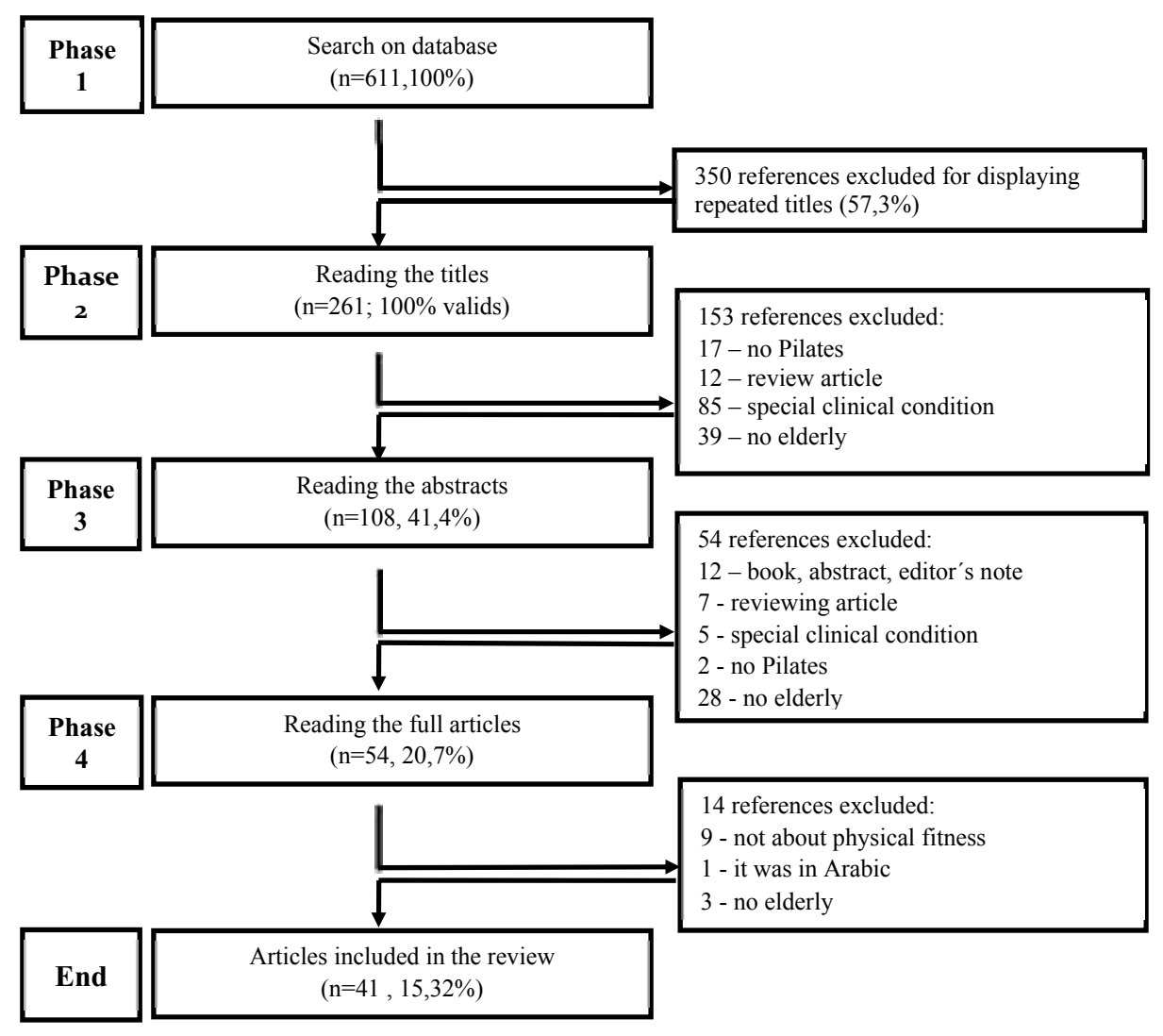

Figure 1. Flowchart of articles selection process.

associated with other variables such as strength and flexibility ${ }^{27}$. In the article by Irez et al. (2011) ${ }^{13}$, the authors conclude that the variables balance, muscle strength and reaction time, together, interfered with a reduction in the number of falls. Corroborating with Irez ${ }^{13}$, studies by Barker ${ }^{23}$ and Mokthari ${ }^{28}$ concluded that strength improvement, when associated with increased balance, was crucial in reducing the risk of falls in the elderly.

Gabizon et al. (2016) ${ }^{29}$ after 12 weeks of Mat Pilates twice a week found no effect on balance. The authors reported that they did not perform any specific balance exercise during this intervention, which may have contributed to this finding. In addition, the study participants'were healthy and independent elderly, so the lack of outcome may be due to a ceiling effect on the tests performed. On the other hand, the intervention may not have been vigorous enough to have an effect. Navega et al. $(2016)^{30}$ found no effect on the static balance of the elderly after Pilates practice. Like Gabizon ${ }^{29}$, he argues that in order to improve balance, specific exercises should be included for this variable and he believes that assigning the improvement of the balance to an indirect increase in muscular strength is to overestimate the results. In fact, current balance recommendations indicate specific exercises that use progressively more difficult postures with gradual reduction of the support base and dynamic movements that disturb the center of gravity, performed 2 to 3 times a week?

\section{Muscle strength}

several studies have investigated muscle strength and concluded that it is possible to improve this variable after the practice of Pilates. In the Barker et al. study ${ }^{23}$ most of the significant changes observed at 24 weeks for the Pilates group were also significant at 12 weeks, suggesting that the changes were achieved within 12 weeks and maintained for an additional 12 weeks of observation. In the programs of Barker ${ }^{23}$, Oliveira et al. (2015) ${ }^{31}$ and Oliveira et al. (2016) ${ }^{32}$ the intensity with which the exercises were performed was moderate, corroborating with the recommendations of the American College, which determines that in order to obtain benefits the elderly must practice strength exercises at least twice a week with moderate to vigorous intensity ${ }^{7}$.

In the reviewed studies the intervention time ranged from 4 to 12 weeks, with 2 to 3 sessions/week, which leads to a variation of the total number of sessions between 12 and 36 sessions. The results of the studies by Bird ${ }^{25}$, with 15 sessions, and of Donath ${ }^{33}$ and Kaesler ${ }^{34}$, with 16 sessions, did not present improvement of muscular strength, whose possible reason is that the little time practiced was not sufficient to promote gains in this variable. On the other hand, Pinheiro et al. ${ }^{35}$, with only 12 sessions, observed a significant improvement in paravertebral muscle strength. In spite of the relatively low number of sessions, in this specific case, the positive results are consistent due to the small sample studied. When it comes to the cases in which a larger number of sessions were recorded (24-36 sessions), there was improvement of muscle strength in all the studies. This leads us to the fact that the results should be analyzed according to the duration of each intervention, and it remains to be seen that, when close to 24 sessions, there are greater benefits in relation to practices limited to a few sessions.

\section{Flexibility}

of the eight studies 9,20,23,24,32,36-38 that assessed flexibility, all found positive effects for at least a certain part of the body. Studies ranged from 8 - 24 weeks of intervention. The study by Guimarães et al. ${ }^{20}$ investigated the flexibility of the hip and shoulder after 12 weeks of Pilates intervention in the apparatus and mat The results showed that there was an increase in flexibility for both the hip and the shoulder, but the results were only significant for the shoulder $(p=0.001)$. The same happened in the study of Fourie $2013^{36}$ where there was improvement of the flexibility of some parts of the body and others did not. In the study by Fourie ${ }^{36}$ after 8 weeks of Mat Pilates there was gain of flexibility for shoulder and hip 
flexion but not for shoulder extension and knee flexion. In that sense, it is necessary to consider whether the exercises included in the program are giving the same muscular emphasis to all the evaluated parts, besides, if the short period of the intervention was enough to cause changes in the flexibility of different parts of the body. Recommendations for flexibility suggest that any activity capable of maintaining or increasing flexibility with moderate intensity should be performed at least 2 times a week?

In Plachy's ${ }^{38}$ 24-week study of Pilates, measurements of various parts of the body were made and all of them had significant changes, suggesting that longer-lasting intervention tends to gain greater gains in flexibility for the whole body. On the other hand, the group that practiced Pilates also practiced water aerobics, so it is not known if this gain in flexibility was by Pilates, by water aerobics or by both.

\section{Functional autonomy}

among the nine studies ${ }^{39-47}$ that assessed functional autonomy, only one ${ }^{46}$ did not improve after the Pilates practice. The variation in the duration of the interventions was large, between 5 and 24 weeks, and it was observed that even studies with a short period of time were efficient in increasing the functional capacity. The study by Duarte ${ }^{41}$ consisted of two periods of Mat Pilates with classes twice a week, each with 5 weeks of class and an interval of 5 weeks without activity between them. Functional autonomy improved after the first period and worsened when the intervention ceased. When the second period of intervention with Pilates and the conversation circles resumed, functional autonomy improved again. Corroborating with this finding, Bertoli et al. ${ }^{39}$ showed that only 6 weeks of Pilates alone were sufficient to significantly improve all variables of functional capacity assessment. The longest study was that of Filho et al. ${ }^{42}$, who evaluated and compared different exercise modalities, including pilates + water aerobics, for 24 weeks, and concluded that, at the end of this period, all modalities increased functional autonomy.

Contrary to the results, Taskiran et al. ${ }^{10}$, compared a group of elderly nursing home residents who practiced Pilates and one who practiced yoga for 8 weeks, observing improvement in strength and flexibility only in the group that practiced yoga. The authors believe that the intention-to-treat analysis may have prevented other parameters from reaching statistical significance, in addition to the small sample and the short duration of the intervention. Another possible justification is that the health condition of the population investigated was already good, so the lack of improvement.

\section{Muscle resistance}

only two ${ }^{38,48}$ studies investigated the effects of Pilates on muscle endurance. Plachy et al. ${ }^{38}$ found, after 6 months of Pilates, positive results to increase muscular endurance in the elderly. The study compared individuals who practiced Pilates three times a week and subjects who practiced Pilates once a week plus twice a week water exercises. Lower limb muscle endurance was assessed through the sit-to-stand test of the Fullerton Functional Fitness Test battery. Both programs proved to be effective in increasing lower extremity muscular endurance, with the group that practiced only Pilates presenting more expressive results. However, important aspects of the practice were not clarified in the study, including whether Pilates was performed on the mat or with apparatus and also aspects of exercise intensity, load and evolution, which makes it difficult to compare with other studies.

Fourie et al. ${ }^{48}$ in their study concluded that 8 weeks of Mat Pilates, 3 times a week, were sufficient to increase the muscular endurance of the elderly. The muscular resistance was measured by the number of squats that the elderly could execute without fatigue. The elderly were evaluated before and after the intervention and there was an increase of $24.48 \pm 11.62$ repetitions to $44.16 \pm 18.97, p=0.000$ after the end of the program. As in the Plachy study (38), no details of intensity, load and evolution of the exercises were reported. In both studies only women were investigated, which prevents us from expanding the findings for both genders. Although the studies present promising results regarding the effects of Pilates on muscle endurance, the evidence is limited because, in addition to the few number of studies, both presented low methodological quality on the PEDro scale.

\section{Body composition}

of the five studies $46,47,49-51$ that investigated the effects of Pilates on body composition, three ${ }^{46,49,51}$ performed their intervention programs with the same duration and weekly frequency ( 8 weeks, three sessions a week), using Mat Pilates. In the study by Fourie ${ }^{49}$ et al. there was a decrease in the percentage of fat and increase in the percentage of lean mass. Contrary to these findings, the studies by Taskiran ${ }^{46}$ and Markovic ${ }^{51}$ found no change in body composition after the end of the program. Although the studies were similar in duration, details such as number of repetitions, evolution in the exercises and intensity were not reported in all studies, which makes it difficult to compare them. In addition, the form of evaluation was different between them. While Fourie ${ }^{49}$ evaluated body composition through skinfold measurements, Taskiran ${ }^{48}$ and Markovic ${ }^{51}$ used bioimpedance, which may explain in part the differences in results. Although the two methods are widely used, there is disagreement in the literature regarding the use of skinfolds in the elderly due to thickness and elasticity of the skin and redistribution of subcutaneous fat, factors that may interfere with the accuracy of the method ${ }^{52}$.

Ruiz Montero et al. ${ }^{50}$ and Vasconcellos et al. ${ }^{47}$ had positive findings in their studies, but in both, Pilates was associated with other aerobic activity, which may have favored the results. Combined activities tend to produce better results than isolated training, particularly for anthropometric measurements and body composition ${ }^{47,53}$. In addition, the duration of their program was much greater than that of the others: in the study of Ruiz Montero et al. ${ }^{50}$ were 24 weeks of intervention and, in the study by Vasconcellos et al. ${ }^{47}, 16$ weeks. Ruiz Montero et al. ${ }^{50}$ performed a program that mixed aerobic activities and Pilates in the same class and observed that at the end of the program there was a decrease in the percentage of fat mass while the percentage of lean mass remained unchanged. Vasconcellos et al. ${ }^{47}$ compared strength group, functional gymnastic group and pilates + water aerobics group, and although the three groups improved body composition and anthropometric measures, the group that practiced Pilates + water aerobics had more expressive results than the others in the loss of weight and decrease in body mass index.

\section{Aerobic resistance}

two studies ${ }^{38,54}$ investigated aerobic resistance and Pilates and the results were positive. After a 24-week Pilates program with three sessions a week Plachy et al. ${ }^{38}$ observed positive results in aerobic endurance in elderly women. The aerobic endurance was measured in two moments: before and after the intervention, through the 6-min walk test. The authors justified this result as a consequence of the greater gain of muscular resistance and also of the increase of muscle control. The same result was confirmed in the study by Vieira et al. ${ }^{54}$ who, after a 12-week program of Mat Pilates, recorded an increase in distance in the 6-min walk test $(\sim 30 \mathrm{~m}, \mathrm{p}<0.01)$. However, the authors advert that the results need to be interpreted with caution since there was also an increase in lower limb strength in the sit-to-stand test, which may have influenced performance in the aerobic endurance test. In fact, this bias will always exist, because muscle strength is one of the variables worked on in a Pilates class. Nevertheless, the results of the studies point in a positive direction, however, the number of studies that support this evidence is reduced. 


\section{CONCLUSION}

Overall, the studies included in this review indicate that the Pilates practice improves the health conditions of the elderly, promoting gain in balance, muscle strength, flexibility, functional autonomy, muscular endurance, body composition and aerobic endurance. Despite these findings, some variables were poorly investigated, and the number of studies relating Pilates for the elderly with certain variables, such as muscular endurance and aerobics, is reduced. Thus, these variables need to be further studied to arrive at some conclusion about the benefits achieved.

The professionals in the area of physical activity can use the results of this review as a basis for preparing programs for Pilates training in the elderly. It was observed that 2-3 sessions/week, for a period between 4-24 weeks, can initiate changes that promote benefits for the physical fitness related to the health of the elderly. Nevertheless, some limitations should be considered in relation to the studies analyzed, such as the limited time of some programs, the limited description of the interventions such as, for example, the specific exercises that were performed, intensity, number of repetitions, number of absences and training of the Pilates professional, and the existence of few studies with high methodological quality.

We emphasize that more studies are needed on the variables that were less investigated, as well as studies that promote longer interventions, with a better description of the methodological details of the program and with greater methodological rigor.

All authors declare no potential conflict of interest related to this article

AUTHORS' CONTRIBUTIONS: Each author made significant individual contributions to this manuscript. GCMFP (0000-0002-7578-4589)*: study design, drafting, review and final approval of the manuscript version; EBN (0000-0003-4507-6562)*: study design, review and final approval of the manuscript version. FJFS (0000-0002-0439-5420)*: review and final approval of the manuscript version. *ORCID (Open Researcher and Contributor ID).

\section{REFERENCES}

1. WHO. World Health Organization. World Health Statistics Geneva, WHO 2011

2. IBGE. Pesquisa Nacional por Amostra de Domicílios: Um Panorama da Saúde no Brasil: Acesso e utilização dos serviços, condições de saúde e fatores de risco e proteção à saúde 2008. 2010: disponível em http:// biblioteca.ibge.gov.br/visualizacao/monografias/GEBIS -\%RJ/panorama.pdf.

3. Mazo G, Liposcki D, Ananda C, Prevê D. Condições de saúde, incidência de quedas e nível de atividade física dos idosos. Rev Bras Fisioter. 2007;11(6):437-42.

4. Mazo GZ, Lopes MA, Benedetti TB. Atividade física e o idoso: concepção gerontológica. Porto Alegre: Editora Sulina; 2004

5. Bocalini DS, dos Santos L, Serra AJ. Physical exercise improves the functional capacity and quality of life in patients with heart failure. Clinics (Sao Paulo). 2008;63(4):437-42.

6. American College of Sports Medicine. ACSM"s Guidelines for Exercising Testing and Prescription. Philadelphia: Lippincot Williams \& Wilkins; 2010

7. Rikli RE, Jones J. Development and validation of a functional fitness test for comunnity-residing older adults. Human Kinetics Journals. 1999;7(2):129-61.

8. Irez GB, Ozdeir RA, Evin R, Irez SG, Korkusuz F. Integrating Pilates exercise into an exercise program for 65+ year-old women to reduce falls. J Sports Sci Med. 2011;10(1):105-11.

9. Benedetti TRB, Borges L, Petroski EL, Gonçalves LHT. Atividade física e estado de saúde mental de idosos. Rev Saúde Pública. 2008;42(2):302-7.

10. Rodrigues BGS, Cader SA, Torres NVOB, Oliveira EM, Dantas EHM. Autonomia funcional de idosas praticantes de Pilates. Functional autonomy of elderly women practicing Pilates. Fisioter Pesqui. 2010;17(7):300-5.

11. USDHHS. Physical activity guidelines for Americans 2008. 2008.

12. Irez GB, Ozdemir RA, Evin R, Irez SG, Korkusuz F. Integrating Pilates exercise into an exercise program for 65+ year-old women to reduce falls. J Sports Sci Med. 2011;10(1):105-11.

13. Shedden M, Kravitz L. Pilates exercise: a research-based review. Journal of Dance Medicine \& Science. 2006;10(3-4):111-6.

14. Verhagen AP, de Vet $H C$, de Bie RA, Kessels AG, Boers M, Bouter LM, et al. The Delphi list: a criteria list for quality assessment of randomized clinical trials for conducting systematic reviews developed by Delphi consensus. J Clin Epidemiol. 1998;51(12):1235-41

15. Cruz-Ferreira A, Fernandes J, Laranjo L, Bernardo LM, Silva A. A Systematic Review of the Effects of Pilates Method of Exercise in Healthy People. Arch Phys Med Rehabil. 2011;92(12):2071-81.

16. Francisco CO, Fagundes AA, Gorges B. Effects of Pilates method in elderly people: systematic review of randomized controlled trials. J Bodyw Mov Ther. 2015;19(3):500-8.

17. Cruz-Ferreira A, Fernandes J, Gomes D, Bernardo LM, Kirkcaldy BD, Barbosa TM, et al. Effects of Pilates-based exercise on life satisfaction, physical self-concept and health status in adult women. Women Health. 2011:51(3):240-55.

18. Aladro-Gonzalvo AR, Machado-Díaz M, Moncada-Jiménez J, Hernández-Elizondo J, Araya-Vargas G. The effect of Pilates exercises on body composition: A systematic review. J Bodyw Mov Ther. 2012;16(1):109-14.

19. Guimarães ACA, Azevedo SF, Simas JPN, Machado Z, Jonck VTF. The effect of Pilates method on elderly flexibility. Fisioter Mov. 2014;27(2):181-8.

20. Hyun J, Hwangbo K, Lee CW. The Effects of Pilates Mat Exercise on the Balance Ability of Elderly Females. J PhysTher Sci. 2014;26(2):291-3.

21. Barker AL, Talevski J, Bohensky MA, Brand CA, Cameron PA, Morello RT. Feasibility of Pilates exercise to decrease falls risk: a pilot randomized controlled trial in community-dwelling older people. Clin Rehabil. 2016;30(10):984-96.

22. Roller M, Kachingwe A, Beling J, Ickes DM, Cabot A, Shrier G. Pilates Reformer exercises for fall risk reduction in older adults: A randomized controlled trial. J Bodyw Mov Ther. 2017;0(0).

23. Bird ML, Hill KD, Fell JW. A randomized controlled study investigating static and dynamic balance in older adults after training with Pilates. Arch Phys Med Rehabil. 2012;93(1):43-9.

24. Bird ML, Fell J. Positive Long-Term Effects of Pilates Exercise on the Age-Related Decline in Balance and Strength in Older, Community-Dwelling Men and Women. J Aging Phys Act. 2014;22(3):342-7.

25. Chang JT, Morton SC, Mojica WA, Maglione M, Suttorp MJ, Roth EZ. Interventions for the prevention of falls in older adults: systematic review and meta-analysis of randomised clinical trials. Br med j. 2004;328(20):1-7.

26. Mokhtari M, Nezakatalhossaini M, Esfarjani F. The Effect of 12-Week Pilates Exercises on Depression and Balance Associated with Falling in the Elderly. Procedia - Social and Behavioral Sciences. 2013;70:1714-23.

27. Gabizon H, Press Y, Volkov I, Melzer I. The Effects of Pilates Training on Balance Control and Self-Reported Health Status in Community-Dwelling Older Adults: A Randomized Controlled Trial. J Aging Phys Act. 2016;24(3):376-83.

28. Navega MT, Furlanetto MG, Lorenzo DM, Morcelli MH, Tozim BM. Effect of the Mat Pilates method on postural balance and thoracic hyperkyphosis among elderly women: a randomized controlled trial. Rev Bras Geriatr Gerontol. 2016;19(3):465-72.

29. Oliveira LC, Oliveira RG, Pires-Oliveira DAA. Effects of Pilates on muscle strenght, postural balance and quality of life of older adults: a randomized, controlled, clinical trial. J Phys Ther Sci. 2015;27(3):871-6.

30. Oliveira LC, Oliveira RG, Pires-Oliveira DA. Comparison between static stretching and the Pilates method on the flexibility of older women. J Bodyw Mov Ther. 2016;20(4):800-6.

31. Donath L, Roth R, Hurlimann C, Zahner L, Faude O. Pilates vs. Balance Training in Health Community -Dwelling Seniors: a 3-arm, Randomized Controlled Trial. Int J Sports Med. 2016;37(3):202-10.

32. Kaesler DS, Mellifont RB, Kelly PS, Taaffe DR. A novel balance exercise program for postural stability in older adults: A pilot study. J Bodyw Mov Ther. 2007:11(1):37-43.

33. Pinheiro KRG, Rocha TCC, Brito NMS, Silva MLGd, Carvalho MEIM, Mesquita LSA, et al. Influência de exercícios de pilates no solo nos músculos estabilizadores lombares em idosas. Rev Bras Cineantropom Desempenho Hum. 2014;16(6):648-57.

34. Fourie M, Gildenhuys GM, Shaw BS, Shaw I, Toriola AL, Ter GD. Effects of a mat pilates program on flexibility in elderly women. Med Sport. 2013;66(4):545-53.

35. Geremia JM, Iskiewicz MM, Marschner RA, Lehnen TE, Lehnen AM. Effect of a physical training program using the Pilates method on flexibility in elderly subjects. Age (Dordr). 2015;37(6):119.

36. Plachy J, Kovách M, Bognár J. Improving Flexibility and Endurance of Elderly Women Through a Six-Month Training Programme. Human Movement. 2018;13(1):22-7.

37. Bertoli J, Biduski GM, de la Rocha Freitas C. Six weeks of Mat Pilates training are enough to improve functional capacity in elderly women. J Bodyw Mov Ther. 2017;21(4):1003-8.

38. Curi VS, Haas AN, Alves-Vilaça J, Fernandes HM. Effects of 16-weeks of Pilates on functional autonomy and life satisfaction among elderly women. J Bodyw Mov Ther. 2018;22(2):424-9.

39. Duarte DS, de Sousa CA, Nunes CRO. Effect of Pilates method and conversation circles on the health of older adults. Fisioter Mov. 2017;30(1):39-48.

40. Mazini Filho ML, Vianna JM, Venturini GRO, de Matos DG, Ferreira MEC. Avaliação de diferentes programas de exercícios físicos na força muscular e autonomia funcional de idosas. Motricidade. 2016;12(S2):124-33.

41. Curi Perez VS, Haas AN, Wolff SS. Analysis of activities in the daily lives of older adults exposed to the Pilates Method. J Bodyw Mov Ther. 2014;18(3):326-31.

42. Rodrigues BGS, Cader AS, Torres NVOB, Oliveira EM, Dantas EHM. Funcional de Idosas Praticantes de Pllates. Fisioter Pesqui. 2010;17(4):300-5.

43. Siqueira Rodrigues BG, Ali Cader S, Bento Torres NV, Oliveira EM, Martin Dantas EH. Pilates method in personal autonomy, static balance and quality of life of elderly females. J Bodyw Mov Ther. 2010;14(2):195-202.

44. Taskiran OO, Cicioglu I, Golgoghani-Zadeh N, Atilgan AD, Bagci E, Gunay M, et al. Do Pilates and Yoga Affect Quality of Life and Physical Performance of Elderly Living in a Nursing Home a Preliminary Study. Turk Geriatri Dergisi. 2014;17(3):262-71.

45. Vasconcelos AP, Cardozo DC, Lucchetti AL, Lucchetti G. Comparison of the effect of different modalities of physical exercise on functionality and anthropometric measurements in community-dwelling older women. J Bodyw Mov Ther. 2016;20(4):851-6.

46. Fourie M, Gildenhuys GM, Shaw I, Toriola AL, Goon DT. Effects of a mat Pilates programme on muscula strenght and endurance in elderly women. AJPHERD. 2012;18(2):299-307.

47. Fourie M, Gildenhuys GM, Shaw I, Shaw BS, Toriola AL, Goon DT. Effects of a Mat Pilates Programme on Body Composition in Elderly Women. West Indian Med J. 2013;62(6):524-8.

48. Ruiz-Montero PJ, Castillo-Rodriguez A, Mikalacki M, Nebojsa C, Korovljev D. 24-weeks Pilates-aerobic and educative training to improve body fat mass in elderly Serbian women. Clin Interv Aging. 2014;9:243-8.

49. Markovic G, Sarabon N, Greblo Z, Krizanic V. Effects of feedback-based balance and core resistance training vs. Pilates training on balance and muscle function in older women: a randomized-controlled trial. Arch Gerontol Geriatr. 2015;61(2):117-23.

50. Rech CR, Cordeiro BA, Petroski EL, Vasconcelos FAG. Utilização da espessura de dobras cutâneas para a estimativa da gordura corporal em idosos. Rev Nutr. 2010;23(1):17-26.

51. Ho SSD SS, Hills AP, Pal S. The effect of 12 weeks of aerobic, resistance or combination exercise training on cardiovascular risk factors in the overweight and obese in a randomized trial. BMC Public Health 2012;12:704.

52. Vieira ND, Testa D, Ruas PC, Salvini TF, Catai AM, Melo RC. The effects of 12 weeks Pilates-inspired exercise training on functional performance in older women: A randomized clinical trial. J Bodyw Mov Ther. 2017;21(2):251-8. 
Apendix 1. Description of the studies published and included in this review regarding the effects of Pilates on physical fitness related to health in the elderly.

\begin{tabular}{|c|c|c|c|c|c|c|}
\hline $\begin{array}{l}\text { Author, Year } \\
\text { (Country) } \\
\text { PEDro Scale }\end{array}$ & Sex, N, Age & $\begin{array}{l}\text { Study design } \\
\text { (use of control } \\
\text { group) }\end{array}$ & Objective & Intervention & Variables / tests & Results \\
\hline $\begin{array}{c}\text { Barker et al, } 2015 \\
\text { (Australia) 6/11 }\end{array}$ & $M F, 53,61-84$ & $\begin{array}{c}\text { Randomized } \\
\text { controlled trial }(Y)\end{array}$ & \begin{tabular}{|c|} 
To evaluate the \\
feasibility of Pilates \\
exercise in older people \\
to decrease falls risk \\
and inform a larger trial.
\end{tabular} & $\begin{array}{c}\text { PG: Pilates equipment, } 12 \text { weeks, } 2 \\
\text { sessions/week, } 60 \text { min }+20 \text { min home } \\
\text { exercise (balance and strengthening } \\
\text { exercises performed in a standing position). } \\
\text { Exercises were individually tailored to } \\
\text { participants' needs and ability but were } \\
\text { intended to be '7 out of } 10 \text { difficulty' for } \\
\text { balance ( } 0-10 \text { scale) and were progressive. } \\
\text { Exercise progressions included sensory } \\
\text { challenges with eyes closed, head turns } \\
\text { or unstable surfaces; dual tasking and } \\
\text { narrowing the base of support. CG: } \\
\text { continued to receive standard care from } \\
\text { their primary healthcare practitioners }+20 \\
\text { min home exercise (same program of PG). }\end{array}$ & $\begin{array}{l}\text { Balance: step test, } \\
\text { functional reach, lateral } \\
\text { reach, timed up and go, } \\
\text { timed tandem stance } \\
\text { and dynamic gait index, } \\
\text { four square step test. } \\
\text { Muscle Strength- timed } \\
\text { sit to stand. Flexibility- } \\
\text { straight leg raise and } \\
\text { knee-to-wall test. }\end{array}$ & $\begin{array}{l}\text { There were significant improvements } \\
\text { ( } p<0.05 \text { ) in the } P G \text { compared with the } \\
C G \text { for five standing balance measures: } \\
\text { step test, functional reach, timed up and } \\
\text { go (fast), timed tandem stance on foam } \\
\text { with eyes closed and dynamic gait index. } \\
\text { Lower-limb strength improved significantly } \\
\text { ( } P=0.012 \text { ) improved in PG compared } \\
\text { with the CG at the } 24-\text {-week follow-up. } \\
\text { There were significant improvements ( } P= \\
0.05 \text { ) in the PG relative to the CG in lower } \\
\text { limb flexibility (straight leg raise), while } \\
\text { both groups improved in the knee-to- } \\
\text { wall test ( } P=0.001 \text { ) without a significant } \\
\text { difference between groups ( } P=0.144) \text {. }\end{array}$ \\
\hline $\begin{array}{l}\text { Bertoli et al, } \\
\text { 2017a (Brazil) } \\
\text { 2/11 }\end{array}$ & $F, 14,62 \pm 3$ & Experimental $(Y)$ & $\begin{array}{l}\text { To analyze the effects of } \\
\text { Mat Pilates on isokinetic } \\
\text { torque of the lower } \\
\text { limbs in elderly women. }\end{array}$ & $\begin{array}{l}\text { The investigation had two periods: } \\
\text { control and intervention. The control } \\
\text { period consisted of the first } 4 \text { weeks of } \\
\text { the study, where no Mat Pilates exercises } \\
\text { were performed and the participants } \\
\text { continued with their normal activities. The } \\
\text { intervention period consisted of Mat Pilates } \\
\text { and accessories, } 12 \text { weeks, } 3 \text { sessions/ } \\
\text { week, } 60 \text { min. Exercises were performed } \\
\text { in } 3 \text { sets, the number of repetitions } \\
\text { increased every } 4 \text { weeks and the difficulty } \\
\text { level progressed from beginner to } \\
\text { intermediate and then advanced. }\end{array}$ & $\begin{array}{l}\text { Muscle Strenght - } \\
\text { isokinetic dynamometer. }\end{array}$ & $\begin{array}{l}\text { The results showed significant } \\
\text { improvements }(p<0.05) \text { in concentric } \\
\text { and eccentric peak torque of knee } \\
\text { flexors muscles, hip flexor and extensor } \\
\text { muscles after } 12 \text { weeks. Mechanical } \\
\text { work showed significant improvement } \\
\text { ( } p<0.05) \text { for knee extensor muscles } \\
\text { during eccentric contractions after week } \\
12 \text {, for hip extensor muscles during } \\
\text { concentric contractions week } 12 \text {, and } \\
\text { for flexor muscles during concentric and } \\
\text { eccentric contractions after week } 12 \text {. }\end{array}$ \\
\hline $\begin{array}{l}\text { Bertoli et } \\
\text { al., 2017b } \\
\text { (Brazil) 2/11 }\end{array}$ & $F, 18,62.3 \pm 2.3$ & Experimental $(Y)$ & $\begin{array}{l}\text { To evaluate the effect } \\
\text { of Mat Pilates on the } \\
\text { functional capacity of } \\
\text { elderly women before } \\
\text { and after six weeks } \\
\text { of intervention. }\end{array}$ & $\begin{array}{l}\text { The investigation had two periods: } \\
\text { control and intervention. The control } \\
\text { period consisted of the first } 4 \text { weeks of } \\
\text { the study, where no Mat Pilates exercises } \\
\text { were performed and the participants } \\
\text { continued with their normal activities } \\
\text { without any kind of physical activity } \\
\text { intervention. The intervention period } \\
\text { consisted of Mat Pilates, } 6 \text { weeks, } 3 \\
\text { session/week, } 60 \text { min. Over the weeks, } \\
\text { difficulty and the number of repetitions } \\
\text { was increased, starting at beginner } \\
\text { and reaching the intermediate level. }\end{array}$ & $\begin{array}{l}\text { Functional capacity- } \\
\text { Timed Up and Go test, } \\
\text { Timed Up Stairs, Timed } \\
\text { Down Stairs, 30-s Chair } \\
\text { Stand, Chair Sit-and } \\
\text { Reach and Back Scratch }\end{array}$ & $\begin{array}{l}\text { Six weeks of Mat Pilates intervention } \\
\text { were enough to improve } \\
\text { significantly all functional capacity } \\
\text { assessment variables }(P<0.05)\end{array}$ \\
\hline $\begin{array}{l}\text { Bird et al., } 2012 \\
\text { (Australia) 6/11 }\end{array}$ & $\begin{array}{l}\mathrm{F} / \mathrm{M}, 32 \\
67.3 \pm 6.5\end{array}$ & $\begin{array}{c}\text { Randomized } \\
\text { controlled trial }(Y)\end{array}$ & $\begin{array}{c}\text { To evaluate effects of } \\
\text { a Pilates intervention } \\
\text { on balance and } \\
\text { function in community- } \\
\text { dwelling older adults. }\end{array}$ & $\begin{array}{l}\text { PG: Circuit style session of Pilates reformer } \\
\text { and mat-based exercises, } 5 \text { weeks, } 2 \\
\text { sessions/week, } 60 \text { min }+1 \text { session/week } \\
\text { mat pilates at home (they received a diary } \\
\text { with exercise description). Progression } \\
\text { occurred whenever possible through } \\
\text { increased load and repetition. CG: did not } \\
\text { receive treatment and were instructed } \\
\text { to maintain their current activities. }\end{array}$ & $\begin{array}{l}\text { Static and dynamic } \\
\text { balance- mediolateral } \\
\text { sway range, Four Square } \\
\text { Step Test, Timed Up and } \\
\text { Go Test. Strength- was } \\
\text { measured for both } \\
\text { legs by using a spring- } \\
\text { based measurement } \\
\text { systemic developed as } \\
\text { part of a battery of fall } \\
\text { risk assessment tests. }\end{array}$ & $\begin{array}{l}\text { PG: There were significant improvements } \\
\text { in all dependent static and dynamic } \\
\text { balance variables }(p<0.001) \text {, but not } \\
\text { for lower-limb strength (knee extensor } \\
\text { strength, } P<.396 \text {; ankle dorsiflexor strength, } \\
\text { P }<.356 \text { ). CG: no changes. There were no } \\
\text { significant differences between the } P G \text { and } \\
\text { CG for any measured variables ( } P<.05 \text { ). }\end{array}$ \\
\hline $\begin{array}{l}\text { Author, Year } \\
\text { (Country) } \\
\text { PEDro Scale }\end{array}$ & Sex, N, Age & $\begin{array}{l}\text { Study Design } \\
\text { (use of control } \\
\text { group) }\end{array}$ & Objective & Intervention & Variables / tests & Results \\
\hline $\begin{array}{l}\text { Curi et al, } 2017 \\
\text { (Brazil) 3/11 }\end{array}$ & $F, 61, \otimes 64,5$ & $\begin{array}{c}\text { Randomized } \\
\text { controlled trial }(Y)\end{array}$ & $\begin{array}{l}\text { To determine the } \\
\text { effects of Pilates-based } \\
\text { mat exercises on } \\
\text { functional autonomy } \\
\text { and life satisfaction } \\
\text { among elderly women. }\end{array}$ & $\begin{array}{l}\text { PG: Mat Pilates, } 16 \text { weeks, } 2 \text { sessions/ } \\
\text { week, } 60 \text { min. Started with exercises } \\
\text { for beginners in the first } 2 \text { weeks and } \\
\text { progressed to intermediate, the number } \\
\text { of repetitions varied between } 3-10 \\
\text { repetitions depending on the exercise. } \\
\text { CG: did not receive treatment. }\end{array}$ & $\begin{array}{l}\text { Functional Autonomy- } \\
\text { Senior Fitness Test. }\end{array}$ & $\begin{array}{l}\text { There was a significant improvement ( } p \\
<0.005) \text { in all variables analyzed for PG. } \\
\text { There was no improvement for } C G \text {. }\end{array}$ \\
\hline $\begin{array}{c}\text { Donath et } \\
\text { al, } 2016 \\
\text { (Switzerland) } \\
5 / 11\end{array}$ & $\mathrm{~F} / \mathrm{M}, 48,>60$ & $\begin{array}{c}\text { Randomized } \\
\text { controlled trial }(Y)\end{array}$ & $\begin{array}{l}\text { To examine effects } \\
\text { of traditional balance } \\
\text { vs. Mat-based } \\
\text { Pilates training on } \\
\text { balance and trunk } \\
\text { strength in healthy } \\
\text { community dwellers. }\end{array}$ & $\begin{array}{l}\text { PG: Mat Pilates, } 8 \text { weeks, } 2 \text { sessions/week. } \\
\text { Six to } 12 \text { repetitions were performed } \\
\text { during each exercise. Training progression } \\
\text { was guaranteed within the } 8 \text { weeks by } \\
\text { modifications and increased repetitions. } \\
\text { BG: same frequency of PG, the main } \\
\text { part was conducted in standing position. } \\
\text { Training progression was ensured by } \\
\text { reducing the base of support, sensory } \\
\text { input and additional tasks. CG: followed } \\
\text { their regular daily activity schemes. }\end{array}$ & $\begin{array}{l}\text { Static and dynamic } \\
\text { balance- force plate } \\
\text { (single limb stance, } \\
\text { perturbed kneeling and } \\
\text { Y-balance test). Trunk } \\
\text { strength- Curl up test. }\end{array}$ & $\begin{array}{l}\text { The PG did not have significant } \\
\text { changes in the variables investigated, } \\
\text { while the } \mathrm{BC} \text { significantly improved } \\
\text { the balance and trunk strength. }\end{array}$ \\
\hline
\end{tabular}




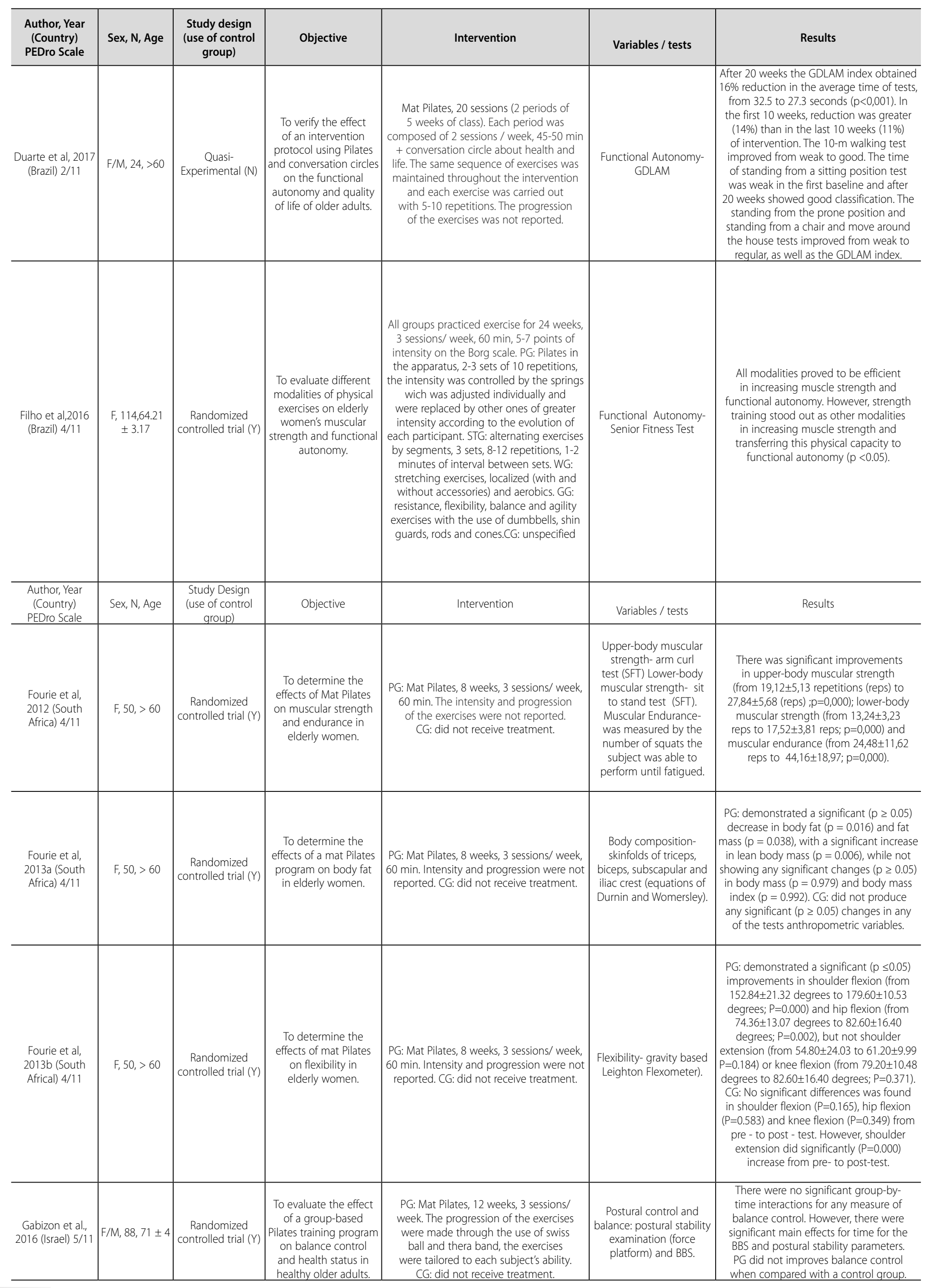




\begin{tabular}{|c|c|c|c|c|c|c|}
\hline $\begin{array}{l}\text { Author, Year } \\
\text { (Country) } \\
\text { PEDro Scale } \\
\end{array}$ & Sex, N, Age & $\begin{array}{l}\text { Study Design } \\
\text { (use of control } \\
\text { group) }\end{array}$ & Objective & Intervention & Variables / tests & Results \\
\hline $\begin{array}{c}\text { Geremia et al, } \\
2015 \text { (Brazil) 1/11 }\end{array}$ & $F / M, 20,70 \pm 4$ & $\begin{array}{c}\text { Quasi- } \\
\text { experimental (N) }\end{array}$ & $\begin{array}{l}\text { To evaluate the } \\
\text { effects of physical } \\
\text { training using the } \\
\text { Pilates method on } \\
\text { body flexibility of } \\
\text { elderly individuals. }\end{array}$ & $\begin{array}{l}\text { Mat Pilates, } 10 \text { weeks, } 3 \text { sessions/week, } 60 \\
\text { min. } 8 \text { to } 10 \text { repetitions were performed } \\
\text { for each exercise, according to their } \\
\text { level of difficulty. The exercise order was } \\
\text { maintained throughout the protocol. The } \\
\text { Borg Rating of Perceived Exertion ( } 6-20 \\
\text { point scale) was used to monitor training } \\
\text { intensity. The rating score was } 12 \text { for the } \\
\text { first } 5 \text { weeks and } 14 \text { for the remaining } \\
5 \text { weeks of the training program. }\end{array}$ & Flexibility- flexometer & 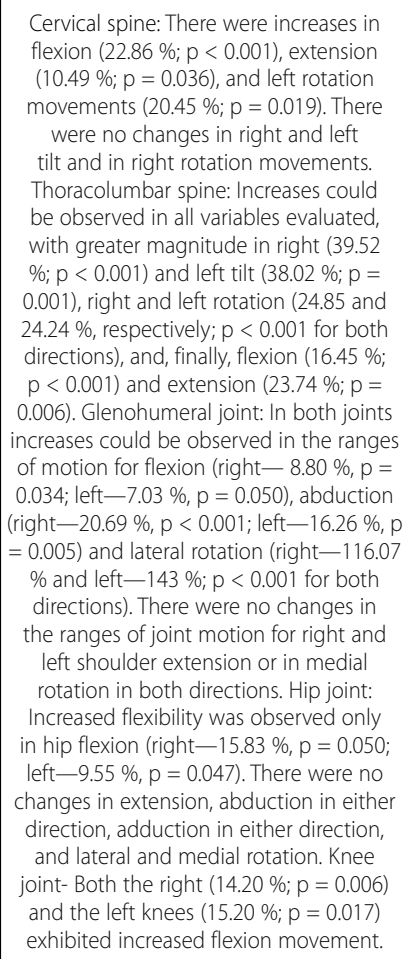 \\
\hline $\begin{array}{c}\text { Guimarães et al, } \\
2014 \text { (Brazil) 2/11 }\end{array}$ & $\begin{array}{l}F / M, 60 \\
68 \pm 5.1\end{array}$ & $\begin{array}{c}\text { Randomized } \\
\text { controlled trial }(Y)\end{array}$ & $\begin{array}{c}\text { To evaluate the effect of } \\
\text { the Pilates method on } \\
\text { the hip and shoulder } \\
\text { girdle flexibility levels } \\
\text { in the elderly. }\end{array}$ & $\begin{array}{l}\text { GP: Pilates machine, mat and with } \\
\text { accessories, } 12 \text { weeks, } 2 \text { sessions/week, } \\
60 \text { min. The intensity of the exercises } \\
\text { was moderate, } 10 \text { to } 12 \text { repetitions } \\
\text { for each exercise. GC: were instructed } \\
\text { to not practiced any kind of physical } \\
\text { activity during the intervention period. }\end{array}$ & $\begin{array}{l}\text { Hip Flexibility- sit and } \\
\text { reach test. Shoulder } \\
\text { Flexibility -behind } \\
\text { the back reach test }\end{array}$ & $\begin{array}{l}\text { PG: concerning hip flexibility, } 60 \% \text { was } \\
\text { considered normal, this percentage raised } \\
\text { to } 66,7 \% \text { in the retest. In the superior } \\
\text { classification we had } 10 \% \text { and there was } \\
\text { a rise of } 33.3 \% \text { in the retest, however } \\
\text { not having significance between the } \\
\text { variables ( } p=0.180 \text { ). On shoulder girdle } \\
\text { flexibility, } 63.3 \% \text { were classified under } \\
\text { normal, and } 16.7 \% \text { on superior flexibility, } \\
\text { changing this number to } 46.7 \% \text { in normal } \\
\text { classification, and to } 33.3 \% \text { on the superior } \\
\text { classification on the retest, within an } \\
\text { increase of } 16.6 \% \text { for the superior variant } \\
\text { on the retest, with significant difference } \\
\text { between the variables ( } p=0,001 \text { ). } \\
\text { CG: no changes between test and retest. }\end{array}$ \\
\hline $\begin{array}{l}\text { Author, Year } \\
\text { (Country) } \\
\text { PEDro Scale }\end{array}$ & Sex, N, Age & $\begin{array}{l}\text { Study design } \\
\text { (use of control } \\
\text { group) }\end{array}$ & Objective & Intervention & Variables / tests & Results \\
\hline $\begin{array}{l}\text { Hyun et al, } 2014 \\
\text { (Republic of } \\
\text { Korea) } 2 / 11\end{array}$ & $F, 40, \geq 65$ & $\begin{array}{c}\text { Quasi- } \\
\text { Experimental (N) }\end{array}$ & $\begin{array}{l}\text { To compare the effects } \\
\text { of Pilates exercise on } \\
\text { a mat and balance } \\
\text { exercise for trunk } \\
\text { stability on the balance } \\
\text { ability of elderly } \\
\text { female subjects. }\end{array}$ & $\begin{array}{l}\text { PG and USSG: } 12 \text { weeks, } 3 \text { sessions/ } \\
\text { week, } 40 \text { min. PG: Mat Pilates, } 1-2 \text { sets } \\
\text { of 2-10 repetitions. USSG: balancing } \\
\text { exercises on an unstable platform. }\end{array}$ & $\begin{array}{c}\text { Static balance- } \\
\text { Romberg's test Dynamic } \\
\text { balance- TUG }\end{array}$ & $\begin{array}{l}\text { After the intervention, sway length, } \\
\text { sway speed and TUG time had } \\
\text { significantly decreased }(p<0.05) \text { in } \\
\text { both groups. A comparison of sway } \\
\text { speed after the intervention between } \\
\text { the two groups revealed that the } \\
\text { PME group showed a larger decrease } \\
\text { than the USSE group }(p<0.05) \text {. }\end{array}$ \\
\hline $\begin{array}{l}\text { Irez et al., } 2011 \\
\text { (Turkey) 8/11 }\end{array}$ & $F, 30, \geq 65$ & $\begin{array}{c}\text { Randomized } \\
\text { controlled trial }(Y)\end{array}$ & $\begin{array}{l}\text { To determine if Pilates } \\
\text { exercise could improve } \\
\text { dynamic balance, } \\
\text { flexibility, reaction time } \\
\text { and muscle strength } \\
\text { in order to reduce } \\
\text { the number of falls } \\
\text { among older women. }\end{array}$ & $\begin{array}{l}\text { PG: Pilates-based mat exercises, thera } \\
\text { band exercises and Pilates ball exercises, } \\
12 \text { weeks, } 3 \text { sessions/week, } 60 \text { min. } \\
\text { The program was divided into three } \\
\text { parts: mat exercises ( }\left(1^{\circ} \text { month), thera }\right. \\
\text { band elastic resistance exercises ( } 2^{\circ} \\
\text { month) and Pilates ball exercises for } \\
\text { beginners ( } 3^{\circ} \text { month). CG: did not } \\
\text { receive treatment and were instructed } \\
\text { to maintain their current activities. }\end{array}$ & $\begin{array}{l}\text { Dynamic balance- } \\
\text { force platform. } \\
\text { Muscle Strength- } \\
\text { Muscle Manual Tester } \\
\text { (Lafayette Company, } \\
\text { Model 01160 Nicholas } \\
\text { Manual Muscle Tester } \\
\text { MMT). Flexibility- } \\
\text { sit and reach test. }\end{array}$ & $\begin{array}{l}\text { The PG improved all the variables } \\
\text { analyzed between the pre and post test } \\
\text { when compared to the } C G(p<0.05) \text {. }\end{array}$ \\
\hline $\begin{array}{c}\text { Irez et al., } 2014 \\
\text { (Turkey) 4/11 }\end{array}$ & $F / M, 45, \geq 65$ & $\begin{array}{c}\text { Randomized } \\
\text { controlled trial }(Y)\end{array}$ & $\begin{array}{c}\text { To compare the effects } \\
\text { of Pilates and a walking } \\
\text { exercise program on } \\
\text { dynamic balance, } \\
\text { flexibility, and muscle } \\
\text { strength, fear of falling } \\
\text { and falling risk among } \\
\text { an elderly population. }\end{array}$ & $\begin{array}{l}\text { PG and WG: } 12 \text { weeks, } 3 \text { sessions/week, } \\
60 \text { min. PG: Pilates-based mat exercises, } \\
\text { thera band exercises and Pilates ball } \\
\text { exercises for beginners, low and moderate } \\
\text { intensity. WG: low and moderate } \\
\text { intensity. CG: did not receive treatment. }\end{array}$ & $\begin{array}{l}\text { Balance-Berg Balance e } \\
\text { ABC Scale. Muscle } \\
\text { strength- muscle } \\
\text { tester (Lafayette } \\
\text { Company, Model } \\
01160 \text { Nicholas Manual } \\
\text { Muscle Tester MMT). }\end{array}$ & $\begin{array}{l}\text { Significant differences }(p<0.05) \text { were } \\
\text { found in all PG variables and in WG } \\
\text { flexibility, no differences were found in CG. }\end{array}$ \\
\hline
\end{tabular}




\begin{tabular}{|c|c|c|c|c|c|c|}
\hline $\begin{array}{l}\text { Author, Year } \\
\text { (Country) } \\
\text { PEDro Scale }\end{array}$ & Sex, N, Age & $\begin{array}{l}\text { Study design } \\
\text { (use of control } \\
\text { group) }\end{array}$ & Objective & Intervention & Variables / tests & Results \\
\hline $\begin{array}{l}\text { Josephs et al., } \\
2016 \text { (United } \\
\text { States) } 4 / 11\end{array}$ & $F / M, 30, \geq 65$ & $\begin{array}{c}\text { Quasi- } \\
\text { Experimental (N) }\end{array}$ & \begin{tabular}{|l|} 
\\
\\
To determine whether \\
Pilates is more effective \\
than traditional \\
strength and balance \\
exercises for improving \\
balance measures, \\
balance confidence \\
and reducing falls \\
in community \\
dwelling older adults \\
with fall risk. \\
\\
\end{tabular} & $\begin{array}{c}\text { PG and TEG: } 12 \text { weeks, } 2 \text { sessions/ week, } 60 \\
\text { min + 15-20 min home exercise (strength } \\
\text { and balance exercises) on non-program } \\
\text { days and daily following discharge from } \\
\text { the program (the same program for both } \\
\text { groups). All patients were asked to work } \\
\text { at level } 12-14 \text { on the Borg Perceived } \\
\text { Exertion Scale (6-20). PG: Pilates apparatus } \\
\text { (Reformer, Chair and Cadillac), } 12 \text { weeks, } \\
2 \text { sessions/ week, } 60 \text { min. Exercises were } \\
\text { individually made more challenging by } \\
\text { altering spring tension, reducing base of } \\
\text { support, adding complexity to the exercise } \\
\text { and altering surface stability. Each exercise } \\
\text { was performed for } 10 \text { repetitions. TEG: } \\
\text { Elastic resistance bands, ankle weights, } \\
\text { foam balance pads, boxes of varying } \\
\text { heights and half foam rollers were props } \\
\text { that were used with the traditional group. } \\
\text { Repetitions of the resistance exercises were } \\
\text { progressed individually. When the patient } \\
\text { could perform } 20 \text { repetitions, the resistance } \\
\text { was increased: elastic resistance bands } \\
\text { were progressed to the next color; ankle } \\
\text { weights were progressed by } 0.5 \text { pounds; } \\
\text { box heights were progressed by } 2 \text { inches. } \\
\end{array}$ & \begin{tabular}{|c} 
Balance- Fullerton \\
Advanced Balance Scale \\
(FAB), Berg Balance \\
Scale, TUG, ABC Scale. \\
\\
TUG \\
(F)
\end{tabular} & $\begin{array}{l}\text { In the TEG, there was a significant } \\
\text { difference (mean difference }=7.45, p=.01 \text { ) } \\
\text { between the pre-test and post-test scores } \\
\text { of the FAB. In the PG there was a significant } \\
\text { difference in the pre-test and post-test } \\
\text { scores of the FAB (mean difference }=6.31 \text {, } \\
p<.05 \text { ) and the ABC (mean difference } \\
=10.57, p=.008 \text { ) respectively. There } \\
\text { were no significant between group } \\
\text { differences on any of the selected tests. }\end{array}$ \\
\hline $\begin{array}{l}\text { Author, Year } \\
\text { (Country) } \\
\text { PEDro Scale }\end{array}$ & Sex, N, Age & $\begin{array}{l}\text { Study Design } \\
\text { (use of control } \\
\text { group) }\end{array}$ & Objective & Intervention & Variables / tests & Results \\
\hline $\begin{array}{c}\text { Kaesler et al. } 2007 \\
\text { (Australia) 1/11 }\end{array}$ & F/M, 8, 66-71 & Quasi- & \begin{tabular}{|} 
To examine the \\
effectiveness of a novel \\
Pilates- inspired exercise \\
program specifically \\
designed to improve \\
balance in an upright \\
position, referred to \\
as postural stability, \\
in older adults.
\end{tabular} & $\begin{array}{l}\text { PG: Pilates equipments (Reformer, Chair, } \\
\text { Caddillac, Thera band and Fit ball), } 8 \text { weeks, } \\
2 \text { sessions/week, } 60 \text { min. All exercises } \\
\text { were modified and/or progressed through } \\
\text { changing the size and shape of the } \\
\text { base of support (e.g. lying to sitting to } \\
\text { standing) and increasing the resistance } \\
\text { of the equipment. All exercises were } \\
\text { repeated twice for } 90 \text { s where subjects } \\
\text { aimed to complete } 15 \text { repetitions each } \\
\text { time. An active rest of } 30 \text { s between } \\
\text { stations allowed for equipment change. }\end{array}$ & $\begin{array}{l}\text { Balance-Test Timed Up } \\
\text { and Go and four stage } \\
\text { balance test. Muscle } \\
\text { strength- sit to stand. }\end{array}$ & $\begin{array}{l}\text { There was a significant improvement } \\
(P<0.05) \text { in some components of static } \\
\text { and dynamic postural sway }(8-27 \%) \text { as } \\
\text { well as the TGUGT }(7 \%) \text { following training. }\end{array}$ \\
\hline $\begin{array}{c}\text { Markovic } \\
\text { et al.,2015 } \\
\text { (Croatia) } 6 / 11\end{array}$ & $F, 34,66-79$ & $\begin{array}{c}\text { Quasi- } \\
\text { Experimental (N) }\end{array}$ & \begin{tabular}{|l|} 
\\
\\
To compare the effects \\
of feedback-based \\
balance and core \\
resistance training \\
utilizing a special \\
computer-controlled \\
device (Huber) with the \\
conventional Pilates \\
training on balance \\
ability, neuromuscular \\
function and body \\
composition of healthy \\
older women. \\
\\
\end{tabular} & $\begin{array}{l}\text { HG and PG: } 8 \text { weeks, } 3 \text { sessions/ week. } \\
\text { PG: Mat Pilates + thera band, } 60 \text { min. Each } \\
\text { exercise was performed for } 2-4 \text { sets with } \\
\text { 15-20s contraction time (isometric exercise) } \\
\text { or } 15-20 \text { repetitions (dynamic exercise). The } \\
\text { difficulty of these exercises was gradually } \\
\text { increased at the earliest opportunity. } \\
\text { HG- Each training session started with } \\
\text { a warm-up phase that included 3-min } \\
\text { mobility/calisthenics exercises. This warm- } \\
\text { up phase was followed by combined core } \\
\text { and balance exercises on the computer- } \\
\text { controlled Huber device lasting } 25-30 \text { min. } \\
\text { The force level ranged from } 50 \% \text { of } \\
\text { maximum voluntary contraction during } \\
\text { the first } 2 \text { weeks, over } 65 \% \text { MVC during } \\
\text { the next } 3 \text { weeks, to } 75 \% \text { of MVC during } \\
\text { the last } 3 \text { weeks. During the first } 2 \text { training } \\
\text { weeks, no balance or core perturbations } \\
\text { were used. During the first } 2 \text { training } \\
\text { weeks, no balance or core perturbations } \\
\text { were used. During the } 3 r d \text { week, core } \\
\text { perturbations were introduced by raising } \\
\text { and lowering the movable column } \\
\text { during isometric exercises. During the } \\
\text { 4th training week, we introduced balance } \\
\text { perturbations via low-velocity rotation } \\
\text { of the movable platform. From the } 5 \text { th } \\
\text { week till the end of the exercise program, } \\
\text { both core and balance perturbations } \\
\text { were included during each exercise. } \\
\end{array}$ & \begin{tabular}{|l} 
\\
\\
Muscle strength- \\
Maximal strength of \\
trunk extensors, flexors \\
and lateral flexors was \\
measured under static \\
conditions using a \\
dynamometer with an \\
embedded force sensor. \\
Upper-body strength (one \\
repetition maximum load; \\
1RM) was measured using \\
a pneumatic bilateral \\
chest press system. \\
Balance- Protocol created \\
by Guiraud et al., 2015 \\
on the force platform. \\
Body composition- \\
bio impedance \\
\end{tabular} & $\begin{array}{l}\text { Post hoc analysis found that both } \\
\text { groups significantly improved upper } \\
\text { limb strength ( } p<0.05 \text {; Cohen 'd = } \\
0.25-0.36 \text { ). The other variables analyzed } \\
\text { improved significantly only for HG. }\end{array}$ \\
\hline $\begin{array}{l}\text { Mesquita et al., } \\
2015 \text { (Brazil) 4/11 }\end{array}$ & $F, 63,60-80$ & $\begin{array}{c}\text { Randomized } \\
\text { controlled trial }(Y)\end{array}$ & \begin{tabular}{c|} 
To compare and \\
examine the effects of \\
two exercise protocols \\
on the balance of \\
elderly women.
\end{tabular} & \begin{tabular}{|} 
PG and PNFG- 4 weeks, 3 sessions/ \\
week, 50 min. PG: Mat Pilates + swiss ball, \\
magic circle and theraband. The number \\
of repetitions and level resistance were \\
increased throughout the study using a \\
Swiss ball, thera band, and magic circle. \\
PNFG: The movements were selected \\
considering all the basic facilitation \\
procedures. The resistance was gradually \\
increased throughout the range of motion. \\
During the first week, 1 set of 10 repetitions \\
for each diagonal was performed; in the \\
second week, 2 sets of 10 repetitions \\
were performed; and in the third and \\
fourth weeks, 3 sets of 10 repetitions were \\
performed.CG: did not receive treatment.
\end{tabular} & $\begin{array}{l}\text { Balance-Force platform, } \\
\text { TUG test, Functional } \\
\text { Reach test, Berg } \\
\text { Balance Scale }\end{array}$ & $\begin{array}{l}\text { The GP women presented better } \\
\text { performance in the functional reach test } \\
\text { and in the TUG than the CG women ( } p \\
<0.05 \text { ). However no significant difference } \\
\text { was observed between GP and GFNP. }\end{array}$ \\
\hline
\end{tabular}




\begin{tabular}{|c|c|c|c|c|c|c|}
\hline $\begin{array}{l}\text { Author, Year } \\
\text { (Country) } \\
\text { PEDro Scale } \\
\end{array}$ & Sex, N, Age & $\begin{array}{c}\text { Study design } \\
\text { (use of control } \\
\text { group) }\end{array}$ & Objective & Intervention & Variables / tests & Results \\
\hline $\begin{array}{l}\text { Mokhtari et. al., } \\
2012 \text { (Iran) 2/11 }\end{array}$ & $F, 30,62-80$ & $\begin{array}{c}\text { Quasi- } \\
\text { experimental }(Y)\end{array}$ & $\begin{array}{c}\text { To investigated the } \\
\text { efficiency of 12-week } \\
\text { Pilates exercises on } \\
\text { depression and balance } \\
\text { associated with falling } \\
\text { in the elderly. }\end{array}$ & $\begin{array}{c}\text { PG: Mat Pilates + theraband, } 12 \text { weeks, } 3 \\
\text { sessions/week, } 60 \text { min. The exercises were } \\
\text { divided into } 2 \text { parts. The first part of training } \\
\text { was performed on the mats ( } 6 \text { weeks) and } \\
\text { the second part of exercises was performed } \\
\text { using bands (the second } 6 \text { weeks).CG: did } \\
\text { not receive treatment and were instructed } \\
\text { to maintain their current activities. }\end{array}$ & $\begin{array}{l}\text { Balance- functional reach } \\
\text { and time up and go }\end{array}$ & $\begin{array}{l}\text { PG: experienced a decrease in time for } \\
\text { functional reach test }(16.7 \%) p=0.037 \text {, and } \\
\text { timed-up-and-go tests }(7.2 \%) p=0,001 \text {. }\end{array}$ \\
\hline $\begin{array}{c}\text { Navega et al., } \\
2016 \text { (Brazil) 3/11 }\end{array}$ & $F, 31,60-75$ & $\begin{array}{c}\text { Randomized } \\
\text { controlled trial }(Y)\end{array}$ & \begin{tabular}{|} 
To evaluate the \\
influence of the Mat \\
Pilates method on \\
thoracic hyperkyphosis \\
and postural balance \\
among elderly women.
\end{tabular} & \begin{tabular}{|c|} 
PG: 8 weeks, 2 sessions/week, 60 min. Each \\
exercise was undertaken progressively, \\
evolving from beginner exercises through \\
to advanced level exercises. In order \\
to advance a level of difficulty, each \\
volunteer had to conduct the exercises \\
according to all of the principles set \\
forth in the Mat Pilates method, which \\
were taught at the beginning of the \\
training period. GC: Attended four \\
lectures about aging and health.
\end{tabular} & Balance- unipodal test & $\begin{array}{l}\text { PG: maintained balance levels ( } p>0.05) \text {. } \\
\text { CG: There was no significant difference } \\
\quad(p>0.005) \text { in any of the variables. }\end{array}$ \\
\hline $\begin{array}{l}\text { Newell et al., } \\
2012 \text { (United } \\
\text { Kingdom) 2/11 }\end{array}$ & F/M, 9, 60-79 & $\begin{array}{l}\text { Quasi- } \\
\text { Experimental (N) }\end{array}$ & $\begin{array}{l}\text { To investigate gait } \\
\text { parameters including } \\
\text { inter-stride variability } \\
\text { and postural sway } \\
\text { in a group of elderly } \\
\text { subjects attending a } \\
\text { weekly Pilates class } \\
\text { over eight weeks. }\end{array}$ & $\begin{array}{c}\text { Mat Pilates + swiss ball, thera } \\
\text { band and wobble board. } 8 \text { weeks, } \\
1 \text { session/ week, } 60 \text { min }\end{array}$ & $\begin{array}{l}\text { Static balance: Biodex } \\
\text { Balance System }\end{array}$ & $\begin{array}{l}\text { Both anterior to posterior sway and } \\
\text { the fall risk index decreased pre - to } \\
\text { post - intervention with the fall } \\
\text { risk index falling by over } 2 \text { points. } \\
\text { However, neither parameter reached } \\
\text { statistical change }(p>0.05) \text {. }\end{array}$ \\
\hline $\begin{array}{l}\text { Oliveira et } \\
\text { al.,2016 a } \\
\text { (Brazil) } 7 / 11\end{array}$ & $F, 32,>60$ & $\begin{array}{c}\text { Quasi- } \\
\text { Experimental (N) }\end{array}$ & $\begin{array}{l}\text { To compare the effects } \\
\text { of static stretching } \\
\text { and Pilates on the } \\
\text { flexibility of healthy } \\
\text { older women. }\end{array}$ & \begin{tabular}{|} 
PG: and SG: 12 weeks, 2 sessions/week \\
,60 min. PG: The equipment used for the \\
exercises was: Chair, Cadillac Trapeze, \\
Reformer and Ladder Barrel. Twenty \\
strengthening and stretching exercises \\
were selected for the main body segments. \\
All exercises were performed in a set \\
of ten repetitions. The intensity of the \\
springs was changed according to the \\
evolution of the strength of the volunteer, \\
maintaining the number of repetitions and \\
sets. SG: The exercises were performed \\
actively, with three sets, held for 30 s each, \\
with a 1 min rest interval between sets, \\
prioritizing the major muscles groups.
\end{tabular} & Flexibility- flexometer & $\begin{array}{l}\text { The static stretching exercises improved } \\
\text { the trunk flexion and hip flexion } \\
\text { movements }(p<0.05) \text {, while the Pilates } \\
\text { improved all evaluated movements }(p< \\
0.05) \text { with Cohen's indicating a large effect } \\
\text { for all variables, except the plantar flexion } \\
\text { movement of the ankle which presented } \\
\text { a medium effect }(d=0.71) \text {. However, over } \\
\text { time, the groups presented differences } \\
\text { only for the trunk extension movement } \\
\text { with a large effect size }(p<0.001, d=1.17)\end{array}$ \\
\hline $\begin{array}{l}\text { Author, Year } \\
\text { (Country) } \\
\text { PEDro Scale }\end{array}$ & Sex, N, Age & $\begin{array}{l}\text { Study design } \\
\text { (use of control } \\
\text { group) }\end{array}$ & Objective & Intervention & Variables / tests & Results \\
\hline $\begin{array}{l}\text { Oliveira } \\
\text { et al.,2017 } \\
\text { (Brazil) } 7 / 11\end{array}$ & $\begin{array}{r}F, 32,64.2 \\
\pm 0.8 \text { years }\end{array}$ & $\begin{array}{c}\text { Randomized } \\
\text { controlled trial }(Y)\end{array}$ & \begin{tabular}{|} 
Investigate the effects \\
of Pilates on the \\
isokinetic muscular \\
strength of the knee \\
extensors and flexors at \\
$60 / s$, in elderly women. \\
\end{tabular} & \begin{tabular}{|} 
PG: and CG: 12 weeks, 2 sessions/ \\
week, 60 min. PG: The equipment used \\
for the exercises was: Chair, Cadillac \\
Trapeze, Reformer and Ladder Barrel. . All \\
exercises were performed in a set of ten \\
repetitions. The intensity of the springs \\
was changed according to the evolution of \\
the strength of the volunteer, maintaining \\
the number of repetitions and sets. A \\
moderate level of effort was maintained \\
during sessions (between Borg 3 and \\
4). GC: The exercises were performed \\
actively, with three sets, held for 30 s each, \\
with a 1 min rest interval between sets, \\
prioritizing the major muscles groups.
\end{tabular} & $\begin{array}{c}\text { Muscle strenght- } \\
\text { Isokinetic dynamometer } \\
\text { Inte }\end{array}$ & $\begin{array}{l}\text { PG: presented a significant improvement } \\
(p<0.01) \text { in all tests performed, when } \\
\text { comparing the pre - and post -intervention } \\
\text { (intragroup), with an effect size (Cohen's } \\
\text { d) reaching } 2.03 \text { and } 1.33 \text { for the knee } \\
\text { flexor and extensor muscles respectively. } \\
\text { CG: There were no significant alterations } \\
(p>0.05 \text { ) in any of the analyzed } \\
\text { variables. The PG presented significant } \\
\text { improvements when compared to } \\
\text { the CG in all tests performed. }\end{array}$ \\
\hline $\begin{array}{l}\text { Oliveira et } \\
\text { al.,2016b } \\
(\text { Brazil }) 8 / 11\end{array}$ & $F, 30,60-70$ & $\begin{array}{c}\text { Randomized } \\
\text { controlled trial }(Y)\end{array}$ & \begin{tabular}{|} 
Verify the influence of \\
Pilates on the isokinetic \\
muscular strength \\
of the elbow flexors \\
and extensors, and \\
on the functionality \\
of the upper limbs, \\
of older women.
\end{tabular} & $\begin{array}{l}\text { PG: The equipment used for the exercises } \\
\text { was: Chair, Cadillac Trapeze, Reformer and } \\
\text { Ladder Barrel. All exercises were performed } \\
\text { in a set of ten repetitions. The intensity } \\
\text { of the springs was changed according } \\
\text { to the evolution of the strength of the } \\
\text { volunteer, maintaining the number of } \\
\text { repetitions and sets. A moderate level of } \\
\text { effort was maintained during sessions } \\
\text { (between Borg } 3 \text { and 4). GC: was instructed } \\
\text { to maintain their usual activities. }\end{array}$ & $\begin{array}{c}\text { Muscle strenght- } \\
\text { Isokinetic dynamometer }\end{array}$ & $\begin{array}{l}\text { In the intra-group comparison, the PG } \\
\text { improved strength of the elbow extensors } \\
\text { and the functionality of the upper limbs } \\
(p<0.05) \text {. When comparing the post- } \\
\text { intervention moment, the PG was superior } \\
\text { to the CG in all variables }(p<0.05) \text {, } \\
\text { with a large effect size }(d>0.80) \text {. }\end{array}$ \\
\hline $\begin{array}{c}\text { Oliveira et. al. } \\
2015 \text { (Brazil) 4/11 }\end{array}$ & $\begin{array}{c}M / F, 32 \\
63.62 \pm 1 y\end{array}$ & $\begin{array}{c}\text { Randomized } \\
\text { controlled trial }(Y)\end{array}$ & $\begin{array}{l}\text { To determine the } \\
\text { effects of Pilates on } \\
\text { lower leg strength, } \\
\text { postural balance } \\
\text { and the health- } \\
\text { related quality of life } \\
\text { of older adults. }\end{array}$ & \begin{tabular}{|c|} 
PG: Pilates equipments, 12 weeks, \\
2 sessions/week, 60 min. \\
Sequence of 20 stretching and \\
strengthening exercises, 1 series of 10 \\
repetitions, moderate intensity (between \\
3-4 Borg Scale), as the participants evolved \\
the load of the springs was increased. GC: \\
20 static stretching exercises, 3 sets of 30 s \\
each, prioritizing large muscle groups.
\end{tabular} & $\begin{array}{l}\text { Muscle strength- } \\
\text { Isokinetic dynamometer. } \\
\text { Balance - Berg Balance } \\
\text { Scale. Functional } \\
\text { mobility- The Timed } \\
\text { Up and Go }\end{array}$ & $\begin{array}{l}\text { In the intragroup analysis, PG showed } \\
\text { a significant improvement in all } \\
\text { variables. In the intergroup analysis, } \\
\text { PG showed significant improvement } \\
\text { in most variables, except for the } \\
\text { Berg Balance Scale }(p=0.0509) \text {. }\end{array}$ \\
\hline
\end{tabular}




\begin{tabular}{|c|c|c|c|c|c|c|}
\hline $\begin{array}{l}\text { Author, Year } \\
\text { (Country) } \\
\text { PEDro Scale }\end{array}$ & Sex, N, Age & $\begin{array}{l}\text { Study design } \\
\text { (use of control } \\
\text { group) }\end{array}$ & Objective & Intervention & Variables / tests & Results \\
\hline $\begin{array}{l}\text { Pata et al., } \\
2013 \text { (United } \\
\text { States) } 4 / 11\end{array}$ & F/M, 35, 61-87 & $\begin{array}{c}\text { Quasi- } \\
\text { Experimental (N) }\end{array}$ & $\begin{array}{c}\text { To determine if a } \\
\text { Pilates- based program } \\
\text { is effective in improving } \\
\text { dynamic balance, } \\
\text { mobility, and postural } \\
\text { stability in order to } \\
\text { decrease the number } \\
\text { of falls in older adults. } \\
\end{array}$ & $\begin{array}{l}\text { Mat Pilates with accessories, } 8 \\
\text { weeks, } 2 \text { sessions/week, 60min. }\end{array}$ & $\begin{array}{l}\text { Balance and fall risk- } \\
\text { Forward reach test. } \\
\text { Functional mobility- TUG. } \\
\text { Postural stability and } \\
\text { fall risk- Turn } 180 \text { test. }\end{array}$ & $\begin{array}{l}\text { Significant improvements were seen } \\
\text { in the TUG test } 1,39 \mathrm{~s}(\mathrm{p}<0.001) \text {, Turn } \\
180 \text { Test }(p=0.002) \text { and } 1.13 \text { inches in } \\
\text { the Forward Reach Test }(p<0.049) \text {. }\end{array}$ \\
\hline $\begin{array}{l}\text { Pérez et al., } 2014 \\
\text { (Brazil) 2/11 }\end{array}$ & $F, 22,65-74$ & $\begin{array}{c}\text { Quasi- } \\
\text { Experimental (N) }\end{array}$ & $\begin{array}{l}\text { To analyze the } \\
\text { Pilates Method to } \\
\text { assess whether it } \\
\text { can help to improve } \\
\text { the performance of } \\
\text { activities that older } \\
\text { adults under- take } \\
\text { in their daily lives. }\end{array}$ & $\begin{array}{l}\text { Mat Pilates, } 12 \text { weeks, } 2 \text { sessions/week, } \\
50 \mathrm{~min} \text {. The exercise protocol was amended } \\
\text { by adding new intermediate-level exercises. }\end{array}$ & $\begin{array}{l}\text { Functional autonomy- } \\
\text { Battery Test of Daily Life } \\
\text { Activities for Physically } \\
\text { Independent Elderly }\end{array}$ & $\begin{array}{l}\text { The results were statistically significant } \\
\text { in most of the tests (error of significance } \\
p<0.05 \text { ), only one (climb steps) did not } \\
\text { present a statistically significant difference. }\end{array}$ \\
\hline $\begin{array}{c}\text { Pinheiro et al., } \\
2014 \text { (Brazil) 1/11 }\end{array}$ & $F, 13,60-80$ & $\begin{array}{c}\text { Quasi- } \\
\text { Experimental (N) }\end{array}$ & \begin{tabular}{|} 
To analyze the effects of \\
Pilates on the strength \\
and conductivity of the \\
electrical stimulation of \\
the lumbar paraspinal \\
muscles as well as \\
muscle contraction \\
transversus abdominis \\
in older women before \\
and after performing \\
Pilates exercises \\
on the ground. \\
\end{tabular} & $\begin{array}{l}\text { Mat Pilates + swiss ball, magic ring and } \\
\text { thera band, } 4 \text { weeks, } 3 \text { sessions/week, } \\
50 \text { min. Stretching and exercises were } \\
\text { performed for the Upper Limbs, trunk and } \\
\text { Lower Limbs, with repetitions and strength } \\
\text { increasing along the exercise weeks. }\end{array}$ & $\begin{array}{l}\text { Muscle strength- surface } \\
\text { electromyography } \\
\text { and Stabilizer Pressure } \\
\text { Biofeedback unit. }\end{array}$ & $\begin{array}{l}\text { There was an increase in paravertebral } \\
\text { muscle strength (from } 18.20 \pm 4.67 \text { to } \\
27.18 \pm 8.37 p=0,001 \text { ), improvements in } \\
\text { the electrical activation of paravertebral } \\
\text { muscles from both the left (before: } \\
35.06 \pm 20.22 ; \text { after: } 49.18 \pm 23.86 \\
p=0,003 \text { ) and right (before: } 32.55 \pm 15.10 \text {; } \\
\text { after: } 45.92 \pm 19.37 p=0,001 \text { ) sides } \\
\text { and improvement of the transverse } \\
\text { abdominal muscle activation (from - } \\
1.66 \pm 1.72 \text { to- } 7.92 \pm 5.78 p<0.003 \text { ). }\end{array}$ \\
\hline $\begin{array}{c}\text { Plachy et al., } 2012 \\
\text { (Hungary) } 3 / 11\end{array}$ & $\begin{array}{l}F, 42,67.1 \\
\quad \pm 4.5\end{array}$ & $\begin{array}{c}\text { Randomized } \\
\text { controlled trial }(Y)\end{array}$ & $\begin{array}{c}\text { To assess whether } \\
\text { two slightly different } \\
\text { half-year-long regular } \\
\text { training programmes } \\
\text { had a positive effect } \\
\text { on flexibility, range of } \\
\text { motion and endurance } \\
\text { in a sample population } \\
\text { of elderly persons. }\end{array}$ & $\begin{array}{l}\text { PG: Pilates } 24 \text { weeks, } 3 \text { sessions/ } \\
\text { week, } 60 \text { min. WAPG- } 2 \text { sessions/ } \\
\text { week of water aerobic }+1 \text { session/ } \\
\text { week of pilates. CG: not reported. }\end{array}$ & \begin{tabular}{|} 
Flexibility: five types \\
of active joint ROM \\
measurements. Aerobic \\
endurance: 6 -minute walk \\
test. Endurance and lower \\
body strength: Sit-to- \\
stand test for 30 seconds
\end{tabular} & $\begin{array}{l}\text { No difference was found in the CG and } \\
\text { for PG and WAPG significant differences } \\
\text { were found in all variables ( } p<0.05 \text { ). }\end{array}$ \\
\hline $\begin{array}{l}\text { Rodrigues } \\
\text { et al., 2010a } \\
\text { (Brazil) 5/11 }\end{array}$ & $F, 52,66 \pm 4$ & $\begin{array}{c}\text { Randomized } \\
\text { controlled trial }(Y)\end{array}$ & $\begin{array}{l}\text { To evaluate the effects } \\
\text { of the Pilates method } \\
\text { on the personal } \\
\text { autonomy, static } \\
\text { balance and quality } \\
\text { of life in healthy } \\
\text { elderly females. }\end{array}$ & $\begin{array}{l}\text { PG: Pilates apparatus (Cadillac, Reformer, } \\
\text { Combo Chair and Wall Unit) + bobath } \\
\text { ball, } 8 \text { weeks, } 2 \text { sessions/week ,60min. } \\
\text { The springs used were the same for } \\
\text { all the volunteers, however, to work } \\
\text { on individual needs, adjustments were } \\
\text { made to the angle in which they were } \\
\text { inserted in the apparatus. Each exercise } \\
\text { was performed for a maximum of } \\
\text { ten repetitions. CG: not reported. }\end{array}$ & $\begin{array}{c}\text { Functional } \\
\text { autonomy:GDLAM } \\
\text { Balance: Tinetti Protocol. }\end{array}$ & $\begin{array}{l}\text { There were significant post-test differences } \\
\text { in the PG in the following areas balance } \\
(\Delta \%=4.35 \%, p=0.0001) \text { and General Index } \\
\text { of GDLAM }(\Delta \%=13.35 \%, p=0.0001) \text {. }\end{array}$ \\
\hline $\begin{array}{l}\text { Rodrigues } \\
\text { et al. ,2010b } \\
\text { (Brazil) } 3 / 11\end{array}$ & $F, 52,66 \pm 4$ & $\begin{array}{c}\text { Randomized } \\
\text { controlled trial }(Y)\end{array}$ & $\begin{array}{l}\text { To assess the effect } \\
\text { of the Pilates method } \\
\text { on elderly women's } \\
\text { functional autonomy. }\end{array}$ & $\begin{array}{l}\text { PG: Pilates apparatus (Cadillac, Reformer, } \\
\text { Combo Chair and Wall Unit) +bobath } \\
\text { ball, } 8 \text { weeks, } 2 \text { sessions/week, } 60 \mathrm{~min} \text {. } \\
\text { Each exercise was performed for a } \\
\text { maximum of ten repetitions and the } \\
\text { intensity was regulated through the } \\
\text { springs. CG: did not receive treatment. }\end{array}$ & $\begin{array}{l}\text { Functional autonomy: } \\
\text { GDLAM. }\end{array}$ & $\begin{array}{l}\text { The PG obtained significantly better } \\
\text { results in all the tests and in the } \\
\text { general GDLAM index }(p=0.035) \text {. }\end{array}$ \\
\hline $\begin{array}{l}\text { Roller et al., } \\
2017 \text { (United } \\
\text { States) } 6 / 11\end{array}$ & F/M, 55, 65-95 & $\begin{array}{c}\text { Randomized } \\
\text { controlled trial }(Y)\end{array}$ & $\begin{array}{l}\text { To investigate the } \\
\text { effects of Pilates } \\
\text { exercises using a } \\
\text { Reformer on measures } \\
\text { of fall risk, balance and } \\
\text { mobility, self-efficacy, } \\
\text { and active range of } \\
\text { motion in adults age } \\
65 \text { and over at risk } \\
\text { for falls compared } \\
\text { to a control group. }\end{array}$ & $\begin{array}{l}\text { PG: Pilates apparatus (Reformer) } 10 \text { weeks, } \\
1 \text { session/week, } 45 \text { min. } 10 \text { exercises with } \\
10 \text { repetitions, the load ranged from } 2 \text { to } \\
4 \text { springs depending on the participant's } \\
\text { ability.CG: did not receive treatment. }\end{array}$ & $\begin{array}{c}\text { Balance- TUG, ABC scale, } \\
\text { SOT, ADT,BBS and } 10 \mathrm{MWT} \\
\text { Flexibility- goniometer }\end{array}$ & $\begin{array}{l}\text { There was a significant interaction } \\
\text { between group and time on the TUG, } \\
\text { BBS, 10MWT, and SLR, hip extension, and } \\
\text { ankle dorsiflexion AROM measurements. } \\
\text { Over time, subjects in the Pilates } \\
\text { intervention group improved their } \\
\text { scores significantly on all mentioned } \\
\text { measures, whereas subjects in the } \\
\text { control group did not }(P<0.05) \text {. }\end{array}$ \\
\hline $\begin{array}{c}\text { Author, Year } \\
\text { (Country) } \\
\text { PEDro Scale }\end{array}$ & Sex, N, Age & $\begin{array}{c}\text { Study design } \\
\text { (use of control } \\
\text { group) }\end{array}$ & Objective & Intervention & Variables / tests & Results \\
\hline $\begin{array}{c}\text { Ruiz-Montero } \\
\text { et al., } 2014 \\
\text { (Spain) 2/11 }\end{array}$ & $F, 303,60-70$ & $\begin{array}{c}\text { Quasi- } \\
\text { Experimental (N) }\end{array}$ & \begin{tabular}{|} 
To examine the \\
differences in \\
anthropometric \\
measurements using \\
an aerobic and Pilates \\
exercise program which \\
lasted 24 weeks.
\end{tabular} & $\begin{array}{l}24 \text { weeks, } 2 \text { sessions/week, 55-60 min. } \\
\text { The training program consisted of } \\
\text { music-based aerobics and Pilates, basic } \\
\text { to intermediate level. The program } \\
\text { comprised Pilates exercises for upper- } \\
\text { and lower-body strength, agility, and } \\
\text { aerobic capacity. During the first session } \\
\text { of the intervention process, participants } \\
\text { were asked their perceived level of } \\
\text { exertion on a scale of 0-10 (Borg scale) } \\
\text { to establish the initial level and then } \\
\text { gradually increase exercise intensity. }\end{array}$ & $\begin{array}{l}\text { Bodyweight- electronic } \\
\text { scale. Skinfold thickness- } \\
\text { caliper with a precision } \\
\text { of } 0.2 \mathrm{~mm} \text {. The equation } \\
\text { used to determine FM } \\
\text { was: corporal density } \\
\text { of Durnin-Womersley. } \\
\text { Girths-flexible metallic } \\
\text { tape measure with a } \\
\text { precision of } 0.1 \mathrm{~mm} \text {. }\end{array}$ & $\begin{array}{l}\text { The percentage of fat mass decreased } \\
\text { significantly (pre-test, } 32.89 \% \text {, } \\
\text { 8.65, post-test, } 28.25 \%, 6.58, P= \\
\text { 0.01). The percentage of lean mass } \\
\text { remained unchanged }(P<0.05 \text { ). }\end{array}$ \\
\hline
\end{tabular}




\begin{tabular}{|c|c|c|c|c|c|c|}
\hline $\begin{array}{l}\text { Author, Year } \\
\text { (Country) } \\
\text { PEDro Scale }\end{array}$ & Sex, N, Age & $\begin{array}{l}\text { Study design } \\
\text { (use of control } \\
\text { group) }\end{array}$ & Objective & Intervention & Variables / tests & Results \\
\hline $\begin{array}{c}\text { Siqueira et al., } \\
2009 \text { (Brazil) 3/11 }\end{array}$ & $F, 52,62-70$ & $\begin{array}{c}\text { Randomized } \\
\text { controlled trial }(Y)\end{array}$ & $\begin{array}{l}\text { To evaluate the effects } \\
\text { of Pilates method } \\
\text { in static balance of } \\
\text { healthy elderly females. }\end{array}$ & $\begin{array}{l}\text { PG: Pilates apparatus (Cadillac, Reformer, } \\
\text { Combo Chair and Wall Unit) + bobath } \\
\text { ball, } 8 \text { weeks, } 2 \text { sessions/week, 60min. } \\
\text { Each exercise was performed for a } \\
\text { maximum of ten repetitions and the } \\
\text { intensity was regulated through the } \\
\text { springs. CG: did not receive treatment. }\end{array}$ & $\begin{array}{l}\text { Static balance: } \\
\text { Tinetti Protocol. }\end{array}$ & $\begin{array}{l}\text { GP presented an evolution of } 1.03 \text { in the } \\
\text { Tinetti protocol total score }(p>0.001) \text {. }\end{array}$ \\
\hline $\begin{array}{c}\text { Sofianidis } \\
\text { et al., } 2016 \\
\text { (Greece) 4/11 }\end{array}$ & F/M, 36 & $\begin{array}{c}\text { Randomized } \\
\text { controlled trial }(Y)\end{array}$ & $\begin{array}{l}\text { To compare the } \\
\text { effects of two different } \\
\text { exercise programs, } \\
\text { Pilates exercise and } \\
\text { Latin dance, on } \\
\text { factors related to } \\
\text { static and dynamic } \\
\text { balance control of } \\
\text { healthy older adults. }\end{array}$ & $\begin{array}{l}12 \text { weeks, } 2 \text { sessions/week, } 60 \text { min. PG: Mat } \\
\text { Pilates with power balls, ribbons-tires and } \\
\text { weights. Each session included exercises } \\
\text { adapted to the age and the purpose of } \\
\text { the intervention GD: each session included } \\
\text { learning of Latin dances appropriate for } \\
\text { their age such as Tango, Rumba, Bachatta } \\
\text { and basic steps of Social-American } \\
\text { System with and without a partner. }\end{array}$ & $\begin{array}{l}\text { Static balance: tandem } \\
\text { stance and one leg } \\
\text { stance. Dynamic } \\
\text { balance: periodic sway } \\
\text { with and without } \\
\text { metronome guidance. }\end{array}$ & $\begin{array}{l}\text { Analysis revealed a significant reduction } \\
\text { of the trunk sway amplitude during the } \\
\text { tandem stance with eyes closed, reduction } \\
\text { in the center of pressure displacement } \\
\text { during one-leg stance, increase in the } \\
\text { amplitude of trunk oscillation during the } \\
\text { sway task for both interventions groups. }\end{array}$ \\
\hline $\begin{array}{c}\text { Taskiran et a.l, } \\
2014 \text { (Turkey) } \\
5 / 11\end{array}$ & $\begin{array}{l}\mathrm{F} / \mathrm{M}, 58 \\
78 \pm 6.8\end{array}$ & $\begin{array}{c}\text { Randomized } \\
\text { controlled trial }(Y)\end{array}$ & $\begin{array}{l}\text { To Investigate whether } \\
\text { Pilates and yoga affect } \\
\text { quality of life and } \\
\text { physical performance } \\
\text { of elderly living in } \\
\text { a nursing home. }\end{array}$ & $\begin{array}{l}\text { PG e YG: } 8 \text { weeks, } 3 \text { sessions/week, } 50 \text { min. } \\
\text { PG: Mat Pilates + weights + elastic bands. } \\
\text { The degree of difficulty and level of the } \\
\text { exercises were modified according to } \\
\text { the performance of the subjects. YG: The } \\
\text { degree of difficulty and duration of the } \\
\text { asanas was increased gently according to } \\
\text { the capacity of the subjects. Each week, } \\
\text { an average of } 7 \text { poses was taught. Each } \\
\text { pose was maintained for } 4 \text { seconds at the } \\
\text { beginning of the training program and } \\
\text { then increased to } 12 \text { seconds at the end. } \\
\text { CG: did not receive treatment } \\
\text { and were instructed to maintain } \\
\text { their current activities. }\end{array}$ & $\begin{array}{l}\text { Functional autonomy- } \\
\text { SFT; Muscle strength- } \\
\text { dinamometer; Balance- } \\
\text { BBS; body composition- } \\
\text { bioimpedance }\end{array}$ & $\begin{array}{l}\text { Measurements of strength and flexibility } \\
\text { tests increased only in } G Y(p=0.017) \\
\text { and ( } p=0.019) \text { respectively, but did not } \\
\text { persist after } 6 \text { months. No changes in } \\
\text { body composition and balance were } \\
\text { observed for any of the groups ( } p<0.05) \text {. }\end{array}$ \\
\hline $\begin{array}{l}\text { Author, Year } \\
\text { (Country) } \\
\text { PEDro Scale } \\
\end{array}$ & Sex, N, Age & $\begin{array}{c}\text { Study design } \\
\text { (use of control } \\
\text { group) } \\
\end{array}$ & Objective & Intervention & Variables / tests & Results \\
\hline $\begin{array}{l}\text { Vasconcelos et al.., } \\
2016 \text { (Brazil) 4/11 }\end{array}$ & $F, 148, \geq 60$ & $\begin{array}{c}\text { Quasi- } \\
\text { experimental (N) }\end{array}$ & $\begin{array}{l}\text { To assess the effect of } \\
\text { different modalities of } \\
\text { physical exercises on } \\
\text { functional capacity } \\
\text { and anthropometric } \\
\text { measurements of } \\
148 \text { older women. }\end{array}$ & $\begin{array}{l}\text { STG, FG, GHP-16 weeks, } 2 \text { sessions/week, } \\
60 \text { min. Moderate to vigorous intensity on } \\
\text { the Borg scale (12 to } 15 \text { points). STG- the } \\
\text { training was prescribed in a circuit format, } \\
\text { entailing three circuits with thirty-second } \\
\text { intervals between exercises, repetition } \\
\text { range of between eight to ten and initial } \\
\text { load corresponding to } 70 \% \text { of the } 10-\mathrm{RM} \\
\text { test on the exercises assessed. FG: physical } \\
\text { resistance and strength exercises for } \\
\text { lower and upper limbs which consisted of } \\
\text { exercises using free weights. The training } \\
\text { was organized in a circuit format with } \\
\text { rest periods, in two sets of ten repetitions } \\
\text { with moderate load and passive rest } \\
\text { of } 1 \text { min between sets. ; WAPG -The } \\
\text { Hydrogymnastics session included aerobic } \\
\text { exercises with focusing on the main } \\
\text { muscle groups with } 1 \text { min per exercise and } \\
30-\text { second active intervals + Mat Pilates, } \\
\text { with volume of } 10 \text { repetitions for exercise. } \\
\end{array}$ & $\begin{array}{l}\text { Functional autonomy- } \\
\text { SFT e anthropometric } \\
\text { measurements / Body } \\
\text { composition- balance, } \\
\text { stadiometer and meter }\end{array}$ & $\begin{array}{l}\text { GHP: significant differences on all } \\
\text { functional tests and anthropometric } \\
\text { measurements. The GHP had greater } \\
\text { weight loss compared to the GF ( } p= \\
0.04 \text { ) and GTF ( } p=0.004 \text { ), reduction in BMI } \\
\text { compared } \\
\text { to the GF ( } p=0.029 \text { ) and GTF ( } p=0.003 \text { ). } \\
\text { There were not differences between } \\
\text { groups in functional test performance. }\end{array}$ \\
\hline $\begin{array}{l}\text { Vieira et al., } 2017 \\
\text { (Brazil) 5/11 }\end{array}$ & $F, 40,60-80$ & $\begin{array}{c}\text { Randomized } \\
\text { controlled trial }(Y)\end{array}$ & $\begin{array}{l}\text { To investigate the } \\
\text { effects of a 12-week } \\
\text { Pilates-inspired exercise } \\
\text { program on the } \\
\text { functional performance } \\
\text { of community-dwelling } \\
\text { older women. }\end{array}$ & $\begin{array}{l}\text { PG: Mat Pilates with accessories, } 12 \text { weeks, } \\
2 \text { sessions/ week, } 60 \text { min. CG: did not } \\
\text { receive treatment and were instructed } \\
\text { to maintain their current activities. }\end{array}$ & $\begin{array}{l}\text { Postural balance- One leg } \\
\text { stance test. Functional } \\
\text { mobility- TUG. Strength } \\
\text { and Dynamic balance- } \\
\text { Five-times sit-to-stand } \\
\text { test. Aerobic capacity- } \\
\text { Six-minute walk test. }\end{array}$ & $\begin{array}{l}\text { PG: time effects were observed for } \\
\text { five-times sit-to-stand }(p=0.03) \text { and } 6 \\
\text { minute-walk tests }(p<0.01) \text {. Only among } \\
\text { PG subjects did the time spent to rise } \\
\text { from a chair and return to a seated } \\
\text { position decrease significantly }(2.0 \mathrm{~s} \\
\text { faster, } p=0.02) \text { and the distance walked } \\
\text { in } 6 \text { min increase }(30 \mathrm{~m}, \mathrm{p}<0.01) \text {. One- } \\
\text { leg stance test and TUG performance } \\
\text { remained unaltered in both groups. }\end{array}$ \\
\hline
\end{tabular}

Female; M: male; PG: Pilates group; CG: control group; BG: balance group; STG: strength training group; WAG: water aerobics group; GG: gym group; USSG: unstable support surface group; WG- walking group; HG: Huber group; PNFG: Confidence; TEG: traditional exercise group; FG: functional group 